\title{
1 Development and experimental validation of an overlay mortar with
}

2 biocide activity

3

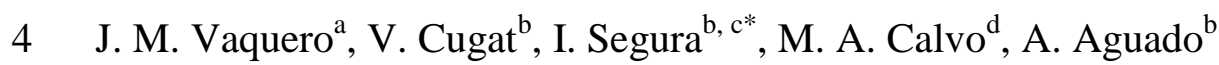

5

6 a BASF Construction Chemicals, Ctra del Mig, 219, 08907 L'Hospitalet del Llobregat, Spain

$7 \quad{ }^{b}$ Department of Construction Engineering, Universitat Politècnica de Catalunya - Barcelona

8 Tech, C1, 08034, Barcelona, Spain

$9 \quad{ }^{c}$ Smart Engineering Ltd., C/Jordi Girona 1-3, Parc UPC - K2M, 08034, Barcelona, Spain

$10{ }^{\mathrm{d}}$ Department of Animal Health and Anatomy, Faculty of Veterinary, Universitat Autònoma 11 de Barcelona, Edifici V, 08193, Bellaterra, Spain

\section{Abstract}

14 Biodeterioration of concrete by microorganism colonisation may be a problem in several

15 structures, especially in irrigation and hydroelectric canals. The main problem in such

16 structures is the proliferation of algae and cyanobacteria that affect the performance of the 17 structure, increase the maintenance costs and affects its durability. A research was conducted 18 to develop a novel cement-based material with biocide activity that can be used as an overlay 19 mortar in existing structures, such as canals and pipes. With this aim, ten commercial biocides 20 were evaluated in a laboratory campaign to assess the effectiveness of the compounds against 21 the microbial colonization of concrete. Both mono- and multicomponent formulations were 22 designed from the commercial products, to increase their antimicrobial effect obtaining a set

\footnotetext{
* Corresponding author: Ignacio Segura Pérez. Universitat Politecnica de Catalunya. Departament d'Enginyeria de la Construcció. Carrer Jordi Girona 1-3, Edifico C1, despacho 202. E-08034 Barcelona. SPAIN. Email: ignacio.segura@upc.edu. Tel.: +34-93-401-65-30. Fax: +34-93-405-41-35
} 
of biocide formulations. The formulations were submitted to a flowchart process to determine

24 their influence on the physical properties of the concrete, evaluate the release of the actives, and their antimicrobial efficiency both before and after accelerated aging processes. During

the campaign, some formulations were observed to diminish the strength of the concrete.

Such behaviour was normally due to the interaction of the active with the cement hydration process. Other formulations showed a high release of active from the concrete in water, compromising the durability of the treatment. In general, monocomponent formulations did not succeed to fulfill all the requirements, thus multicomponent formulations were analysed.

One studied multicomponent formulation presented particularly good results in all properties analysed. This product did not significantly change the properties of concrete and the release of active in water from the concrete was low, while the antimicrobial effects were long lasting.

\section{Keywords}

Biocide; Mortar; Cement; Bioreceptivity; Colonisation; Algae; Bacteria; Fungi

\section{Introduction}

Concrete is one of the most used construction materials because it has high structural performance, long durability, and a relatively low cost. The surface of concrete is resistant to corrosion and provides a physically and chemically stable environment that can be exposed to potable water or wastewater; for this reason, it is commonly used in pipes and canals (Alum et al., 2008). In these structures, microorganisms can easily colonise concrete and cause biodeterioration of the material. The main problem in irrigation and hydroelectric canals is the growth of algae and cyanobacteria among other microorganisms on the canal walls. This biological growth creates many problems that are reflected in increased maintenance costs. 
The effective section of the canal is decreased and the roughness coefficient of the canal wall

49 is increased, which diminishes the water flow (Lancar and Krake, 2002). Some studies reflect 50 a decrease of $10 \%$ in the hydroelectric generation capacity because of algal growth 51 (Andrewartha et al., 2007; Perkins et al., 2009). Furthermore, it is worth noting that presence 52 of some types of fungi can have detrimental effects in concrete walls as well as can affect 53 production of certain cereals, as Fusarium (Giannantonio at al., 2009). Moreover, the 54 detachment of filamentous organisms such as green algae carries the risk of clogging and 55 plugging filters. Both the growth of these organisms on concrete and the required cleaning

Algal growth is usually preceded by concrete biofouling. This phenomenon is often grouped in the literature into several stages that include an initial accumulation of adsorbed organics, the settlement and growth of pioneering bacteria creating a biofilm matrix and the subsequent succession of micro and macrofoulers (Chambers et al., 2006). Usually, bacteria play a dominant role in the formation of this biofilm and further colonisation of larger microorganisms (Wei et al., 2013).

Several antimicrobial treatments have been used in concrete and cement-based materials. Conventional studied procedures involve the usage of water repellents, biocides, or both. Water repellents slow the adsorption of water by reducing the surface energy and capillary forces of the concrete, thus decreasing the bioreceptivity of the material. Biocides focus on decreasing biological activity. While the use of hydrophobic compounds alone was shown to be insufficient in inhibiting microbial growth, the application of a combination of both 
73 treatments has been reported as effective (Urzì and De Leo, 2007; De Muynck et al., 2009).

74 The order of application of the different products influences the efficiency of the final treatment; this must be considered to avoid negative effects (Malagodi et al., 2000; Nugari and Salvadori, 2003; Moreau et al., 2008).

Biocide treatments have one of two mechanisms: the elimination of the microorganisms already present on the material, and the prevention and control of microbial re-colonisation on clean surfaces. Many compounds have been analysed and tested over the years, including zeolites supporting heavy metal ions (such as copper and silver), zinc oxide, silver nanoparticles, pyridine biocides, silver nitrate, and quaternary ammonium compounds, or Quats (Urzì and De Leo, 2007; Alum et al., 2008; De Muynck et al., 2009; Eyssautier-Chuine et al., 2015). Quats are most frequently used because they have good efficacy as algaecides (Nugari et al., 2009). Nevertheless, this issue is far from being solved from a scientifically and technically point of view.

The main aim of this paper is to present the results obtained in a research devoted to the development of cement-based materials with biocide activity to be used as a biocide mortar layout in existing concrete structures (Vaquero, 2013; Aguado et al., 2014). Therefore, different commercially available antimicrobial products were evaluated for effectiveness against microbial colonisation in concrete. These products were chosen for cost-effectiveness, non-toxicity, and capacity as disinfectants in other applications, such as floor and wall coverings. Different combinations of the commercial biocides were considered to increase their antimicrobial effect obtaining a set of biocide formulations. The experimental campaign was designed to evaluate the influence of the incorporation of the biocide formulations in concrete properties and their antimicrobial activity. Furthermore, the durability of the biocide 
activity was also evaluated through accelerated aging processes. The performances of the

99 different combinations studied are shown and analysed, with special attention to the reasons responsible for the failure of the formulations.

\section{Materials and methods}

\subsection{Concrete specimens}

104 Concrete specimens were fabricated with the dosage shown in Table 1. The cement selected 105 to produce the different mixtures was a CEM II A/V 42.5R. All aggregates were siliceous 106 with a low fraction of particles under $0.125 \mathrm{~mm}$ sieve. The largest aggregate size was selected 07 according to the size of the Petri dishes utilized for the microbiological tests. Furthermore, a 108 large water-to-cement (w/c) ratio of the mixes (0.7) was used to obtain samples with high 109 porosities that favoured microbiological colonisation. Lastly, a plasticiser additive (Pozzolith $110475 \mathrm{~N}$, BASF Construction Chemicals) was added to each mixture based on percentage over 111 cement weight (\% ocw). All concrete samples were made according to EN 12390-2 (AENOR, 112 2009a). The samples were cured in a curing chamber $\left(20^{\circ} \pm 2{ }^{\circ} \mathrm{C} ; 95 \pm 5 \%\right.$ relative humidity $)$ 113 for 28 days.

115 Table 1. Concrete dosages for reference and biocide mixtures

\begin{tabular}{|l|l|}
\hline Compound & Dosage $\left(\mathbf{k g} / \mathbf{m}^{\mathbf{3}}\right)$ \\
\hline Cement & 350 \\
\hline Fine aggregate $(0-5 \mathrm{~mm})$ & 1074 \\
\hline Coarse aggregate $(5-12 \mathrm{~mm})$ & 724 \\
\hline Plasticiser & $3.5(1 \%)$ \\
\hline Water & 244 \\
\hline
\end{tabular}




\subsection{Design of biocide formulations}

Table 2. General information on the different antimicrobial products evaluated

\begin{tabular}{|c|c|c|c|c|}
\hline Number & Active & $\begin{array}{c}\text { Commercial } \\
\text { name }\end{array}$ & Effect & $\begin{array}{c}\text { Physical } \\
\text { state }\end{array}$ \\
\hline 1 & $\begin{array}{l}\text { bis(2-pyridylthio)zinc } 1,1^{\prime}- \\
\text { dioxide (Zinc pyrithione } 10 \% \text { ) }\end{array}$ & $\begin{array}{l}\text { ACTICIDE SR } \\
1288 \AA\end{array}$ & $\begin{array}{c}\text { Fungicide and } \\
\text { bactericide }\end{array}$ & Liquid \\
\hline 2 & $\begin{array}{c}\text { 1,2,3,6-Tetrahydro-N- } \\
\text { (trichloromethylthio)phthalimide }\end{array}$ & BIOPOL D 212® & Fungicide & Powder \\
\hline 3 & $\begin{array}{c}\text { Dithio-2,2'- } \\
\text { bis(benzmethylamide) }\end{array}$ & DENSIL P® & $\begin{array}{c}\text { Fungicide and } \\
\text { bactericide }\end{array}$ & Liquid \\
\hline 4 & $\begin{array}{l}\text { 2-pyridinethiol-1- } \mathrm{NaO}+1,2- \\
\text { benzisothiazole-3 }(2 \mathrm{H}) \text {-one }\end{array}$ & P 24-81 & $\begin{array}{c}\text { Fungicide and } \\
\text { bactericide }\end{array}$ & Powder \\
\hline 5 & $\begin{array}{l}\text { bis(2-pyridylthio)zinc 1,1'- } \\
\text { dioxide (Zinc pyrithione } 10 \% \text { ) }\end{array}$ & ВC 98-56 & $\begin{array}{c}\text { Fungicide and } \\
\text { bactericide }\end{array}$ & Powder \\
\hline 6 & $\begin{array}{l}\text { n-Butyl-1,2-benzisothiazolin-3- } \\
\text { one }\end{array}$ & VANQUISH 100® & $\begin{array}{l}\text { Fungicide, } \\
\text { bactericide } \\
\text { and } \\
\text { algaecide }\end{array}$ & Liquid \\
\hline 7 & $\begin{array}{c}\text { Poly(hexamethylene biguanide) } \\
\text { hydrochloride }\end{array}$ & VANTOCIL IB ${ }^{\circledR}$ & Bactericide & Liquid \\
\hline 8 & $\begin{array}{l}\text { 2-octyl-2H-isothiazol-3-one }+ \\
\text { Terbutryn }\end{array}$ & $\begin{array}{c}\text { ACTICIDE SR } \\
1453 \AA\end{array}$ & $\begin{array}{l}\text { Algaecide and } \\
\text { fungicide }\end{array}$ & Powder \\
\hline 9 & $\begin{array}{c}\text { n-Tert-butyl-N-cyclopropyl-6- } \\
\text { (methylthio)-1,3,5-triazine-2,4- } \\
\text { diamine }+2 \text { Octyl-2H- } \\
\text { isothiazol-3-one }\end{array}$ & ACTICIDE MBP® & $\begin{array}{c}\text { Bactericide } \\
\text { and fungicide }\end{array}$ & Powder \\
\hline 10 & $\begin{array}{l}\text { 2,4,4'-trichloro-2'-hydroxy- } \\
\text { diphenyl ether }\end{array}$ & $\begin{array}{l}\text { IRGASAN DP } \\
300 \circledR\end{array}$ & $\begin{array}{l}\text { Bactericide } \\
\text { and fungicide }\end{array}$ & Powder \\
\hline
\end{tabular}

Ten commercially available antimicrobial products (Table 2) were tested during the experimental campaign. These products were chosen for cost-effectiveness, non-toxicity, and capacity as disinfectants in other applications, such as floor and wall coverings. The antimicrobial products shown in Table 2 were used to develop different formulations for cement-based biocides. These biocide formulations were composed of one (monocomponent) or several antimicrobial products (multicomponent) as well as incorporating different additives in some cases (see Table 3). Multicomponent formulations were designed to achieve as wide a spectrum of antimicrobial action as possible. The content of each component of the formulations is given between brackets, expressed as percentage of the formulation. 
Table 3. General information on the biocide formulations

\begin{tabular}{|c|c|c|c|}
\hline \multicolumn{2}{|c|}{ Formulation name } & Active number & Additives \\
\hline \multirow{10}{*}{ 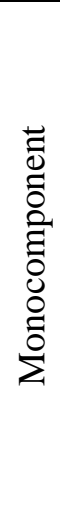 } & BXT & 1 & Calcium filler $(20 \%)$ \\
\hline & BIOPOL D212 & 2 & - \\
\hline & DENSIL P & 3 & - \\
\hline & P24-81 & 4 & - \\
\hline & BC 98-56 & 5 & - \\
\hline & VANQUISH 100 & 6 & - \\
\hline & VANTOCIL IB & 7 & - \\
\hline & ACTICIDE MBP & 9 & - \\
\hline & $\mathrm{BXT} / 11$ & 10 & PG $(59.7 \%)$, TIBP $(0.3 \%)$, water $(15 \%)$ \\
\hline & $\mathrm{BXT} / \mathrm{AB}$ & 10 & PG (74.44\%), TIBP (0.45\%), BUBLEX® (0.11) \\
\hline \multirow{5}{*}{ 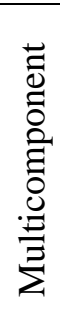 } & $\mathrm{BXT} / 1$ & $1(16 \%), 8(59 \%)$ & MOUSSEX® $(4 \%)$, water $(21 \%)$ \\
\hline & $\mathrm{BXT} / 5$ & $1(8 \%), 10(3.45 \%)$ & $\begin{array}{c}\text { PG }(10 \%), \text { PEG }(10 \%), \operatorname{TIBP}(0.15 \%), \\
\text { OPTIGEL CR® }(1.5 \%)\end{array}$ \\
\hline & $\mathrm{BXT} / 10 \mathrm{P}$ & $9(15 \%), 10(4 \%)$ & MOUSSEX® $(0.3 \%)$, Calcium filler (80.7) \\
\hline & $\mathrm{BXT} / 12 \mathrm{C}$ & $1(5.12 \%), 10(5 \%)$ & $\begin{array}{c}\text { PG (12.23\%), PEG }(77.34 \%), \text { TIBP }(0.21 \%), \\
\text { BUBLEX® }(0.1 \%)\end{array}$ \\
\hline & PL-UV-H-2B & $8(30 \%), 10(15 \%)$ & MOUSSEX® (4\%), Calcium filler (51\%) \\
\hline
\end{tabular}

132

As Table 3 shows, some additives were incorporated to improve the physical properties of the mixture. MOUSSEX®, BUBLEX®, and tri-isobutyl phosphate (TIBP) are used as defoamer compounds to avoid air entrapment in the concrete mix; propylene and polyethylene glycol (PG and PEG, respectively) are used as solvents instead of water to allow the solubilisation of the antimicrobial products and the collection of liquid admixtures; OPTIGEL CR ${ }^{\circledR}$ is an activated bentonite product used for anti-settling and stabilizing in water-based systems. Finally, calcium filler is used as a dispersive matrix for the biostatic agents. The biocide formulations were incorporated in the concrete mix in different amounts, as listed in Table 4; the dosage is expressed as percentage over dry weight of the mix (\% odw). Concrete specimens were fabricated for each formulation dosage. Furthermore, reference samples were made for each biocide formulation without since cement samples may vary over time. These quantities were chosen based on the recommendations of the manufacturers of the products. Table 4 also provides information of the content of active principle in the formulations; in 
146 case of multicomponent formulations, individual and total contents are given for each

1
147 antimicrobial product.

149 Table 4. Dosage of the biocide formulations and active contents

\begin{tabular}{|c|c|c|c|c|c|}
\hline \multirow{2}{*}{\multicolumn{2}{|c|}{ Formulation name }} & \multirow{2}{*}{ Dosage (\% odw) } & \multicolumn{3}{|c|}{ Active content $(\mathrm{kg} / \mathrm{m} 3)$} \\
\hline & & & \multirow{2}{*}{$\begin{array}{c}\mathrm{A} \\
0.859\end{array}$} & \multirow{2}{*}{$\begin{array}{l}\mathrm{B} \\
-\end{array}$} & \multirow{2}{*}{$\begin{array}{l}\text { Total } \\
0.859\end{array}$} \\
\hline \multirow{30}{*}{ 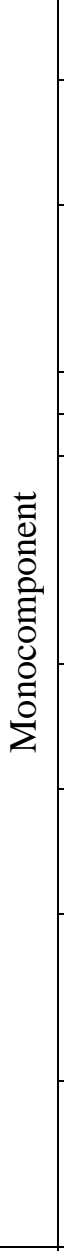 } & \multirow{2}{*}{ BXT } & 0.05 & & & \\
\hline & & 0.15 & 2.578 & - & 2.578 \\
\hline & \multirow{3}{*}{ BIOPOL D212 } & 0.1 & 2.148 & - & 2.148 \\
\hline & & 0.2 & 4.296 & - & 4.296 \\
\hline & & 0.3 & 6.444 & - & 6.444 \\
\hline & \multirow{4}{*}{ DENSIL P } & 0.2 & 4.296 & - & 4.296 \\
\hline & & 0.5 & 10.740 & - & 10.740 \\
\hline & & 1 & 21.480 & - & 21.480 \\
\hline & & 2 & 42.960 & - & 42.960 \\
\hline & P24-81 & 0.3 & 6.444 & - & 6.444 \\
\hline & BC 98-56 & 0.3 & 6.444 & - & 6.444 \\
\hline & \multirow{5}{*}{ VANQUISH 100} & 0.002 & 0.043 & - & 0.043 \\
\hline & & 0.013 & 0.279 & - & 0.279 \\
\hline & & 0.025 & 0.537 & - & 0.537 \\
\hline & & 0.037 & 0.795 & - & 0.795 \\
\hline & & 0.05 & 1.074 & - & 1.074 \\
\hline & \multirow{3}{*}{ VANTOCIL IB } & 0.3 & 6.444 & - & 6.444 \\
\hline & & 0.6 & 12.888 & - & 12.888 \\
\hline & & 1 & 21.480 & - & 21.480 \\
\hline & \multirow{3}{*}{ ACTICIDE MBP } & 0.1 & 2.148 & - & 2.148 \\
\hline & & 0.4 & 8.592 & - & 8.592 \\
\hline & & 0.8 & 17.184 & - & 17.184 \\
\hline & \multirow{4}{*}{ BXT/11 } & 0.15 & 0.806 & - & 0.806 \\
\hline & & 0.18 & 0.967 & - & 0.967 \\
\hline & & 0.2 & 1.074 & - & 1.074 \\
\hline & & 0.22 & 1.181 & - & 1.181 \\
\hline & \multirow{4}{*}{$\mathrm{BXT} / \mathrm{AB}$} & 0.01 & 0.054 & - & 0.054 \\
\hline & & 0.05 & 0.269 & - & 0.269 \\
\hline & & 0.1 & 0.537 & - & 0.537 \\
\hline & & 0.15 & 0.806 & - & 0.806 \\
\hline \multirow{14}{*}{ 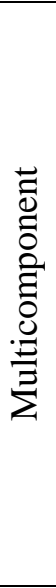 } & \multirow{3}{*}{$\mathrm{BXT} / 1$} & 2.5 & 8.592 & 31.683 & 40.275 \\
\hline & & 3 & 10.310 & 38.020 & 48.330 \\
\hline & & 3.5 & 12.029 & 44.356 & 56.385 \\
\hline & \multirow{4}{*}{$\mathrm{BXT} / 5$} & 0.075 & 0.056 & 0.129 & 0.184 \\
\hline & & 0.15 & 0.111 & 0.258 & 0.369 \\
\hline & & 0.2 & 0.148 & 0.344 & 0.492 \\
\hline & & 0.4 & 0.296 & 0.687 & 0.984 \\
\hline & \multirow{2}{*}{$\mathrm{BXT} / 10 \mathrm{P}$} & 0.8 & 0.687 & 2.578 & 3.265 \\
\hline & & 1 & 0.859 & 3.222 & 4.081 \\
\hline & \multirow{2}{*}{$\mathrm{BXT} / 12 \mathrm{C}$} & 0.1 & 0.110 & 0.107 & 0.217 \\
\hline & & 0.6 & 0.660 & 0.644 & 1.304 \\
\hline & \multirow{3}{*}{ PL-UV-H-2B } & 0.15 & 0.483 & 0.967 & 1.450 \\
\hline & & 0.2 & 0.644 & 1.289 & 1.933 \\
\hline & & 0.3 & 0.967 & 1.933 & 2.900 \\
\hline
\end{tabular}




\subsection{Experimental campaign}

152 The experimental campaign was designed as a flowchart, as described in Figure 1 with three consecutive main phases. Firstly, the influence of the different biocide formulations on physical properties of concrete was determined. Secondly, those biocide concretes that passed the first phase were subjected to a release test to determine the amount of active released from the sample. Finally, microbiological tests were conducted in those samples that passed the previous phases. The evaluation of antimicrobial properties was conducted twice, before and after an accelerated aging test, to simulate adverse conditions and thus estimate the durability of the tested treatment.

161 Figure 1. Flowchart of the experimental campaign

\subsubsection{Physical characterisation of concrete specimens}

Concrete specimens were characterised to determine the influence of the biostatic formulations on the physical properties of the samples. Several parameters were considered in both the fresh and hardened state. Workability and density were characterised in the fresh concrete. The workability of the mixes was determined according to the ISO 1920-2 standard (ISO, 2005). The characterisation of the hardened concrete samples included density and mechanical properties determinations (compressive and flexural strength). The compressive and flexural strength measurements were made following EN 12390-4 and 5, respectively (AENOR, 2009b; c).

\subsubsection{Release of active}

Following the physical characterization of the concrete samples, release tests were performed to determine the amount of the active released from the samples. The method described in 
prEN 16105:2010 (AENOR, 2010) is usually applied to evaluate leaching of substances from

coatings and paints. Thus, it was selected to evaluate the release of active from the concrete samples, as the cement-based biocide developed is intended to be used as an overlay mortar for existing structures. This method subjects the samples to wetting-drying cycles to simulate the effects of rain and environmental conditions. After the wetting-drying cycles, the water samples are analysed to determine the amount of active released from the samples.

183 Samples for the release tests were obtained from the same concrete dosages described 184 previously. All samples presented at least $100 \mathrm{~cm}^{2}$ of surface area and with weights 185 characterised both before and after the tests. For each analysis, duplicate samples of each 186 biocide mixture were studied. Furthermore, one reference sample was also analysed. All 187 samples were maintained for 7 days at $23^{\circ} \pm 2^{\circ} \mathrm{C}$ at a relative humidity of $50 \pm 5 \%$. The 188 subsequent immersion process lasted 24 days. During that time, nine wetting-drying cycles 189 were performed on days $1,3,7,9,14,16,18,22$, and 24. Each cycle contained the following 190 steps: $1 \mathrm{~h}$ immersion, $4 \mathrm{~h}$ drying, $1 \mathrm{~h}$ immersion, and $48 \mathrm{~h}$ drying. At the end of the cycle, the 191 water samples were collected and analysed by HPLC analyses and $\mathrm{pH}$ measurements.

193 The amount of active present in the solution after the release tests can be expressed according 194 to Eq. (1). Here, $M$ is the amount of active expressed in $\mathrm{mg} / \mathrm{m}^{2} \cdot$ day, $c$ is the measured 195 concentration of active in the eluate in $\mathrm{mg} / \mathrm{L}, V_{\text {real }}$ is the real volume of eluate after each 196 immersion day in L, $A$ is the effective surface area exposed to the releasing test in $\mathrm{m}^{2}$, and $t$ is 197 the day of immersion.

$$
M=\frac{c \cdot V_{\text {real }}}{A \cdot t}
$$




\subsubsection{Evaluation of antimicrobial properties}

The different concrete samples were tested to determine their antimicrobial properties both before and after accelerated aging processes to estimate the durability of the treatments. Several samples from the different concrete mixes were exposed to suspensions containing different microorganisms. The characteristics of the microorganisms used are described in Table 5. The microorganisms were collected from different culture media from the American Type Culture Collection (ATCC) and the Sammlung von Algenkulturen Göttingen (SAG).

209 incubation periods thereof

\begin{tabular}{|c|c|c|c|c|c|}
\hline \multirow{2}{*}{$\begin{array}{c}\text { Type of } \\
\text { microorganism }\end{array}$} & \multirow[b]{2}{*}{ Microorganism } & \multirow{2}{*}{$\begin{array}{l}\text { Reference } \\
\text { code }\end{array}$} & \multicolumn{3}{|c|}{ Incubation period } \\
\hline & & & Agar type & $\begin{array}{c}\text { Temperature } \\
\left({ }^{\circ} \mathrm{C}\right)\end{array}$ & $\begin{array}{l}\text { Time } \\
\text { (days) }\end{array}$ \\
\hline Fungus & $\begin{array}{l}\text { Aspergillus } \\
\text { niger }\end{array}$ & ATCC 6275 & $\begin{array}{l}\text { Malt extract } \\
\quad \text { agar }\end{array}$ & $25 \pm 2$ & $5-7$ \\
\hline Bacteria & $\begin{array}{c}\text { Staphylococcus } \\
\text { aureus }\end{array}$ & ATCC 6538P & \multirow{2}{*}{$\begin{array}{l}\text { Nutrient } \\
\text { agar }\end{array}$} & $30 \pm 2$ & 2 \\
\hline Bacteria & Escherichia coli & ATCC 8739 & & $30 \pm 2$ & 2 \\
\hline Algae & $\begin{array}{c}\text { Scenedesmus } \\
\text { vaculatus }\end{array}$ & SAG 211-8b & \multirow{2}{*}{$\begin{array}{l}\text { Kuhl } \\
\text { solution }\end{array}$} & $20 \pm 2$ & 21 \\
\hline Algae & $\begin{array}{c}\text { Stichococcus } \\
\text { bacillaris }\end{array}$ & SAG 379-1a & & $20 \pm 2$ & 21 \\
\hline
\end{tabular}

211 The concrete samples were located in Petri dishes containing agar media specialized for each

212 microorganism. The concrete samples were of $10 \mathrm{~mm}$ thickness and variable sizes, obtained 213 from the samples described in section 2.3. The different microorganism suspensions were 214 spread over the agar surface. Each suspension contained at least $5 \times 10^{6}$ organisms per $\mathrm{mL}$. 215 The Petri dishes with the concrete samples and the suspensions were incubated as detailed in 216 Table 5. At the end of the incubation period, the antimicrobial properties of the samples were 217 evaluated. The samples were visually analysed to determine the growth of the 218 microorganisms and classified by the following scale: 0 - no visible growth of 
microorganisms; 1 - slight observable growth of microorganisms; 2 - evident growth of

microorganisms and presence of spores.

As mentioned above, after the first evaluation of the antimicrobial properties an accelerated aging process was conducted to simulate the adverse conditions concrete can experience, thus evaluating antimicrobial efficiency over time. The exposure test Xenotest 150S was performed. This test was designed to evaluate the durability of paints and varnishes, and consists of an uninterrupted irradiation of the samples for $2000 \mathrm{~h}$ with $340 \mathrm{~nm}$ radiation at a radiant flux of $0.5 \mathrm{~W} / \mathrm{m}^{2}$, in UNE-EN ISO 4892-2 (AENOR, 2014) standard conditions. This treatment is equivalent to 6-8 months of continuous strong sunlight. By using ultraviolet fluorescent lamps and irrigation sprinklers, the process simulates environmental wear accrued over a much longer period than actually experienced. The samples exposed to the accelerated aging process and others with the same characteristics without aging were evaluated a second time with respect to antimicrobial properties, and the differences in the capacity of the samples to inhibit microbial growth were compared and examined.

\section{Results and discussion}

\subsection{General evaluation}

During the experimental campaign, the biocide formulations shown in Table 3 were submitted to the flowchart process described in section 2.2. Those that did not present good results in a given phase were immediately discarded from the experiment to save time and cost. At first, only monocomponent formulations were evaluated. None of them was able to pass the whole evaluation process, as shown in Table 6. Some of the formulations failed in the physical properties evaluation phase (BXT/AB, BXT/11, VANQUISH 100, DENSIL P and BC 98-56); 
243 formulations BIOPOL D212 and VANTOCIL IB did not passed releasing tests; finally,

6

ACTICIDE MBP, P24-82 and BXT were discarded after the antimicrobial test.

Considering these results, multicomponent formulations were tested to increase the antimicrobial activity and/or to overcome the problems observed during the first evaluation phase. Five multicomponent formulations were designed and analysed. Only one of the multicomponent formulations (PL-UV-H-2B) presented good results during the complete evaluation process. Table 6 presents a summary of the phase at which the formulation was discarded.

253 Table 6. Failure phases and qualification of each formulation during the experimental 254 campaign

\begin{tabular}{|c|c|c|}
\hline & Formulation & Failure phase \\
\hline \multirow{10}{*}{ 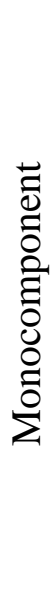 } & $\mathrm{BXT} / \mathrm{AB}$ & Physical properties \\
\hline & $\mathrm{BXT} / 11$ & Physical properties \\
\hline & ACTICIDE MBP & Antimicrobial properties (before aging process) \\
\hline & BIOPOL D212 & Releasing test \\
\hline & VANTOCIL IB & Releasing test \\
\hline & VANQUISH 100 & Physical properties \\
\hline & DENSIL P & Physical properties \\
\hline & P24-81 & Antimicrobial properties (before aging process) \\
\hline & BC 98-56 & Physical properties \\
\hline & BXT & Antimicrobial properties (after aging process) \\
\hline \multirow{5}{*}{ 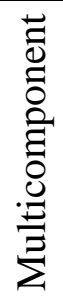 } & $\mathrm{BXT} / 12 \mathrm{C}$ & Physical properties \\
\hline & $\mathrm{BXT} / 10 \mathrm{P}$ & Physical properties \\
\hline & $\mathrm{BXT} / 1$ & Physical properties \\
\hline & $\mathrm{BXT} / 5$ & Antimicrobial properties (before aging process) \\
\hline & PL-UV-H-2B & None \\
\hline
\end{tabular}




\subsection{Physical characterisation}

259 Firstly, the results obtained by the monocomponent formulations will be analysed. Five out of

ten of the monocomponent formulations affected the physical properties of the concrete

\begin{tabular}{|c|c|c|c|c|c|c|c|}
\hline \multirow{3}{*}{$\begin{array}{c}\text { Formulation } \\
\text { name }\end{array}$} & \multirow{3}{*}{$\begin{array}{c}\text { Dosage } \\
\text { (\% } \\
\text { odw) }\end{array}$} & \multirow{3}{*}{$\begin{array}{l}\text { Flow } \\
(\mathbf{m m})\end{array}$} & \multirow{3}{*}{$\begin{array}{c}\text { Fresh } \\
\text { density } \\
\left(\mathbf{k g} / \mathbf{m}^{3}\right)\end{array}$} & \multicolumn{4}{|c|}{ Mechanical properties (MPa) } \\
\hline & & & & \multicolumn{2}{|c|}{$\begin{array}{c}\text { Compressive } \\
\text { strength }\end{array}$} & \multicolumn{2}{|c|}{$\begin{array}{l}\text { Flexural } \\
\text { strength }\end{array}$} \\
\hline & & & & $1 \mathrm{~d}$ & $28 d$ & 1d & 28d \\
\hline \multirow{5}{*}{ DENSIL P } & 0 & 154 & 2450 & 19.1 & 47.8 & 4.8 & 8.2 \\
\hline & 0.2 & 154 & 2435 & 19.3 & 48.3 & 4.6 & 9.4 \\
\hline & 0.5 & 155 & 2435 & 8.5 & 41.1 & 2.2 & 7.2 \\
\hline & 1.0 & 155 & 2435 & 4.4 & 42.1 & 1.2 & 8.3 \\
\hline & 2.0 & 159 & 2422 & n.d. & 34.2 & n.d. & 7.3 \\
\hline \multirow{2}{*}{ BC 98-56 } & 0 & 150 & 2432 & 12.8 & 33.5 & 3.5 & 6.8 \\
\hline & 0.3 & 135 & 2465 & n.d. & 36.6 & n.d. & 7.6 \\
\hline \multirow{6}{*}{ VANQUISH 100} & 0 & 155 & 2450 & 15.4 & 33.6 & 3.3 & 6.5 \\
\hline & 0.002 & 152 & 2392 & 14.2 & 33.1 & 2.9 & 6.1 \\
\hline & 0.013 & 152 & 2401 & 13.1 & 29.2 & 2.8 & 5.6 \\
\hline & 0.025 & 153 & 2417 & 13.4 & 27.4 & 3.0 & 5.5 \\
\hline & 0.037 & 156 & 2439 & 12.8 & 30.9 & 3.0 & 5.4 \\
\hline & 0.050 & 150 & 2427 & 12.8 & 27.4 & 2.5 & 5.8 \\
\hline \multirow{5}{*}{$\mathrm{BXT} / 11$} & 0 & 117 & 2389 & 15.5 & 35.1 & 3.2 & 5.6 \\
\hline & 0.15 & 118 & 2005 & 5.3 & 16.0 & 2.1 & 3.3 \\
\hline & 0.18 & 122 & 2004 & 7.2 & 21.4 & 2.5 & 5.2 \\
\hline & 0.20 & 121 & 2122 & 6.9 & 20.9 & 2.7 & 5.3 \\
\hline & 0.22 & 127 & 2174 & 9.6 & 24.3 & 2.4 & 5.8 \\
\hline \multirow{5}{*}{$\mathrm{BXT} / \mathrm{AB}$} & 0 & 117 & 2389 & 15.5 & 35.1 & 3.2 & 5.6 \\
\hline & 0.01 & 120 & 2420 & 15.1 & 29.9 & 2.6 & 5.4 \\
\hline & 0.05 & 125 & 2395 & 14.8 & 34.3 & 2.8 & 5.4 \\
\hline & 0.10 & 128 & 2467 & 13.0 & 31.8 & 2.3 & 5.0 \\
\hline & 0.15 & 124 & 2397 & 11.9 & 29.8 & 2.1 & 4.9 \\
\hline
\end{tabular}

267 The results shown in Table 7 direct evidence the biocide formulations affected the concrete

samples in two different ways. The first phenomenon observed was the influence of the active 
principles in the cement hydration process. Most of the formulations exhibited this

phenomenon. The formulations BXT/AB, VANQUISH 100 and DENSIL P mainly influenced early-age properties of the concrete samples. Concrete samples made with these formulations presented results similar to those from the reference concrete regarding workability and density, with variations lower than $5 \%$ in these properties. However, the mechanical resistances decreased significantly, especially at lower ages. The reduction of compressive strength increases with increased biocide formulation dosages, e.g.: concrete samples made with $\mathrm{BXT} / \mathrm{AB}$ formulation reached a $23 \%$ reduction of compressive strength with a dose of $0.15 \%$ at 1 day, and a $35 \%$ reduction of flexural strength at the same dose and age. In this case, the active principles are retarding the cement hydration process thus reducing compressive and flexural strengths in relation to the reference samples. The strengths obtained at 28 days showed slight recovery, although they remained below the reference value.

292 The second phenomenon observed was air-entrapment, evidenced in concrete samples made 293 with BXT/11 formulation. This formulation was designed with the same active principle as

BC 98-56 formulation also influenced the cement hydration process but in a different way. This formulation modified the workability of the concrete samples by increasing the viscosity of the fresh mix. A strong diminution of the resistances at $24 \mathrm{~h}$ was observed and the samples could not be demoulded. Mechanical properties at 28 days were higher than those of the reference concrete were. This behaviour could be explained by the influence of the active principle on the cement hydration process, generating smaller but more proliferate crystals. Consequently, the crystallization process would be slower and the resistances would increase with age. 
$\mathrm{BXT} / \mathrm{AB}$, but with a reduced amount of propylene glycol and water substituted to improve the

stability of the solution. With this reduction, the amount of defoamer compound was also decreased; only TIBP was used. In these samples, significant reductions were observed in their densities. The addition of IRGASAN DP 300® produced air entrapment in the concrete mix and diminished the density, thus requiring increased amounts of defoamer to release entrapped air. Another important aspect was observed regarding to the densities of the antimicrobial samples. The increased amount of biostatic agent in the mix did not produce a proportional reduction of the densities, but quite the opposite; as the content of biocide increased, the density also increased. This phenomenon may result from the increased amount of biostatic agent being accompanied by an increased amount of defoamer compounds in the concrete, thus reducing air entrapment. The influence of the formulation on the densities of the mixtures produced significant reductions in the strength values, with a maximum diminution of $66 \%$ in compressive strength with a dose of $0.15 \%$ at 1 day.

Regarding the multicomponent formulations evaluated, most of them did not present good results during the evaluation of their mechanical performance. This was the case for BXT/1, $\mathrm{BXT} / 10 \mathrm{P}$, and $\mathrm{BXT} / 12 \mathrm{C}$; the compressive and flexural strengths of these compounds are shown in Table 8, as well as the workability and density measurements in fresh state. A trend in both compressive and flexural strengths of the concrete samples is observed; the decreases in strength are directly proportional to the increases of biocide contents in the mixtures. The controlling factor in this decrease of strength is again the influence of the active principles in the cement hydration process. Minor influences are observed in workability and density in fresh state of the concrete samples as compared with the reference samples. Nevertheless, large reductions in compressive strength are observed for the samples containing BXT/1, 
318 BXT/10P, and BXT/12C formulations. Furthermore, samples with BXT/1 formulation could

1

Table 8. Mechanical properties of the multicomponent formulations

\begin{tabular}{|c|c|c|c|c|c|c|c|}
\hline \multirow{3}{*}{$\begin{array}{c}\text { Formulation } \\
\text { name }\end{array}$} & \multirow{3}{*}{$\begin{array}{c}\text { Dosage } \\
(\% \\
\text { odw })\end{array}$} & \multirow{3}{*}{$\begin{array}{l}\text { Flow } \\
(\mathrm{mm})\end{array}$} & \multirow{3}{*}{$\begin{array}{c}\text { Fresh } \\
\text { density } \\
\left(\mathrm{kg} / \mathrm{m}^{3}\right)\end{array}$} & \multicolumn{4}{|c|}{ Mechanical properties (MPa) } \\
\hline & & & & \multicolumn{2}{|c|}{$\begin{array}{c}\text { Compressive } \\
\text { strength }\end{array}$} & \multicolumn{2}{|c|}{$\begin{array}{l}\text { Flexural } \\
\text { strength }\end{array}$} \\
\hline & & & & $1 \mathrm{~d}$ & 28d & $1 d$ & 28d \\
\hline \multirow{4}{*}{$\mathrm{BXT} / 1$} & 0 & 157 & 2426 & 12.5 & 36.7 & 3.7 & 7.5 \\
\hline & 0.4 & 150 & 2465 & n.d. & 34.0 & n.d. & 6.7 \\
\hline & 0.45 & 153 & 2439 & n.d. & 31.2 & n.d. & 6.5 \\
\hline & 0.5 & 149 & 2468 & n.d. & 34.3 & n.d. & 6.3 \\
\hline \multirow{5}{*}{$\mathrm{BXT} / 5$} & 0 & 165 & 2343 & 15.8 & 42.3 & 4.8 & 8.7 \\
\hline & 0.08 & 170 & 2337 & 14.9 & 40.5 & 4.3 & 8.1 \\
\hline & 0.15 & 167 & 2381 & 15.1 & 40.0 & 3.8 & 8.4 \\
\hline & 0.2 & 165 & 2330 & 14.5 & 39.0 & 3.5 & 7.9 \\
\hline & 0.4 & 168 & 2327 & 14.0 & 39.0 & 3.3 & 7.7 \\
\hline \multirow{3}{*}{$\mathrm{BXT} / 10 \mathrm{P}$} & 0 & 125 & 2473 & 19.1 & 35.0 & 4.8 & 7.2 \\
\hline & 0.8 & 117 & 2266 & 10.3 & 30.6 & 2.8 & 6.1 \\
\hline & 1 & 120 & 2200 & 8.2 & 29.0 & 2.5 & 6.0 \\
\hline \multirow{3}{*}{$\mathrm{BXT} / 12 \mathrm{C}$} & 0 & 117 & 2389 & 12.8 & 33.5 & 3.5 & 6.8 \\
\hline & 0.6 & 120 & 2420 & 8.1 & 28.4 & 2.8 & 5.6 \\
\hline & 1 & 125 & 2395 & 6.2 & 22.7 & 2.3 & 4.4 \\
\hline \multirow{4}{*}{ PL-UV-H-2B } & 0 & 148 & 2523 & 14.3 & 37.1 & 4.0 & 9.4 \\
\hline & 0.15 & 152 & 2501 & 12.7 & 36.9 & 3.5 & 8.6 \\
\hline & 0.2 & 145 & 2479 & 11.3 & 35.7 & 2.8 & 8.2 \\
\hline & 0.3 & 150 & 2484 & 14.0 & 34.9 & 3.2 & 8.5 \\
\hline
\end{tabular}

323 Only BXT/12C and PL-UV-H-2B formulations did not significantly change the physical 324 properties of the concrete mixtures. Both fresh and apparent densities are in the same range of 325 values, with differences under $2 \%$. Minor reductions in the fresh density of samples 326 elaborated with the highest dosage of PL-UC-H-2B formulation are observed. This reduction 327 is related with an air-entrapping process, since the formulation was designed as a solid 328 powder because of the difficulties of obtaining a stable suspension of the antimicrobial 329 products. Although minor variations of compressive and flexural strength are observed, these 
are negligible and do not evidence shortcomings in the mechanical performances of the concretes.

\subsection{Release of active}

Releasing tests were made in those monocomponent formulations that succeeded the first phase of physical characterization (ACTICIDE MBP, BIOPOL D212, VANTOCIL IB, P2481, and BXT). The releasing curves of the actives from concrete samples containing each formulation are shown in Figure 2; in the case of P24-81 formulation, separated curves are shown for each active (NaP: 2-pyridinethiol-1-NaO; BIT: 1,2-benzisothiazole-3(2H)-one). For each formulation, daily and accumulated concentrations are given on the right and left side of the figure, respectively). According to the same procedure used in the physical characterization tests, the formulations that did not present good results in this phase were discarded, as occurred with the monocomponent formulations Biopol D212 and Vantocil IB (see Figure $2 b$ and 2c). Although the releasing levels of Biopol D212 are far from toxicity, as the value considered detrimental for humans of this product is $\mathrm{LD}_{50}>9000 \mathrm{ppm}$, this high solubility in water could quickly decrease the antimicrobial efficiency of the treated concrete.

347 The formulation seemed excessively soluble for the intended purpose and thus it was 348 discarded. Similar behaviour was observed with the formulation Vantocil IB in the releasing 349 test. The amount of active released increases as the dosage of the antimicrobial mixture is 350 increased, for both formulations.

352 Figure 2. Releasing curves of the active from concrete fabricated with monocomponent 353 formulations: a) ACTICIDE MBP, b) BIOPOL D212, c) VANTOCIL IB, d) P24-81, and e) 354 BXT 
Regarding the multicomponent formulations, releasing tests were made only in PL-UV-H-2B formulations since BXT/5 formulation is comparable to monocomponent formulations ACTICIDE MBP and BXT. The releasing curves of the active from concrete samples containing the formulation PL-UV-H-2B are shown in Figure 3; separated curves are provided for each active present in the formulation (OIT: 2-octyl-2H-isothiazol-3-one; TER: terbutryn). As expected, an increase in the actives released is observed with increasing dosages of the formulation. For the sample with $0.15 \%$ dosage of the formulation, the actives are mainly released during the first 9 days of the test. Afterwards, only minor releasing is observed. The sample with $0.2 \%$ dosage presents higher released quantities of actives throughout the releasing test. An anomalous measurement at 14 days is much higher for OIT than the rest $\left(0.45 \mathrm{mg} / \mathrm{m}^{2}\right)$. If this value is not considered, the total amount of active released from the sample is proportional to the initial content of the active in the concrete sample.

Figure 3. Releasing curves of the active from concrete fabricated with PL-UV-H-2B formulation

For the highest tested dosage of PL-UV-H-2B formulation $(0.3 \%)$, the quantities of active released are much larger than the ones for the other dosages. The release of active from the sample during the first 7 days is approximately six times greater compared to the results of the $0.15 \%$ sample, thus increasing until the end of the process. The total active released from the $0.3 \%$ sample is more than nine times larger than that from the $0.15 \%$ sample. This behaviour suggests possible interactions between the active and the cementitious matrix. However, as the content of formulation is increased above $0.2 \%$, there is more free active in the pore solution; hence, the active released increases during the duration of the test. The total amount 
of active released throughout the test is far below toxic values. The sample with the largest

content of formulation releases a total amount of $1.52 \mathrm{mg} / \mathrm{m}^{2}$ of actives, which is equivalent to $0.3 \mathrm{ppm}$. This antimicrobial product is considered toxic for humans at $\mathrm{LD}_{50}>2360 \mathrm{ppm}$, which is almost four orders of magnitude larger than the total amount of active released from the sample during the releasing test.

\subsection{Evaluation of the antimicrobial properties}

387 The final phase of the experimental campaign was only performed on those formulations that 388 had presented good results in both previous phases, as described in sections 3.2 and 3.3. Three monocomponent formulations (ACTICIDE MBP, P 24-81, and BXT) were evaluated, but none presented good results after the process. Two multicomponent formulations (BXT/5 and PL-UV-H-2B) were also subjected to the microbiological test.

Firstly, the results obtained by concrete samples fabricated with ACTICIDE MBP formulation will be presented. This monocomponent formulation was expected to have bactericide and fungicide activity. Therefore, it was tested against three microorganisms (Escherichia coli, Staphylococcus aureus, and Aspergillus niger). Figure 6 depicts images of the evaluation of the antimicrobial tests performed with this formulation. The concrete samples show good efficiency against Staphylococcus aureus, preventing biological growth on the surface with a growth index of 0 in all treated samples; the reference sample presents a growth index of 2. However, the concrete samples do not inhibit surface growth of Escherichia coli or Aspergillus niger, presenting a growth index of 2 at all dosages. Since the antimicrobial 402 activity against two of the three microorganisms is negligible, the product is considered not 403 valid. 
405 Figure 4. Effectiveness of concrete made with Acticide MBP formulation against different

microorganisms

Secondly, concrete samples made with P 24-81 formulation were analysed; the results of the antimicrobial tests are shown in Figure 5. This formulation was also expected to present bactericide and fungicide activity; it was tested against the same microorganisms as samples made with ACTICIDE MBP formulation. The treated samples contained $0.3 \%$ odw. After the microbiological test, the compound presented no antimicrobial properties against any microorganism, with no inhibition of biological growth on the surface of the sample. The visual analysis (see Figure 5) showed a growth index of 2 in all cases; hence, it was also discarded before the accelerated aging process.

417 Figure 5. Effectiveness of concrete made with $\mathrm{P}$ 24-81 formulation against different 418 microorganisms

420 Finally, BXT formulation was analysed. This product was expected to have biocide and fungicide activity. In initial antimicrobial tests, shown in Figure 6a, the product exhibits good antimicrobial properties against both types of bacteria, with a growth index of 0 in every case. Nevertheless, the effect against the Aspergillus niger fungus is only acceptable with the dosage of $0.15 \%$ with a growth index of 1 ; this index has a value of 2 for the sample with the lowest dose of $0.05 \%$. The results are considered sufficient for validity, and the samples were submitted to the accelerated aging test. A second antimicrobial test was conducted following the same procedure. After aging, the inhibition of bacterial growth is retained, as seen in Figure $6 \mathrm{~b}$, with a growth index of 0 in all cases. However, the antimicrobial activity against 
Aspergillus niger is not preserved, as the growth index reaches 2 with both dosages; thus, the product is considered not valid.

Figure 6. Effectiveness of concrete made with BXT formulation against different microorganisms: a) before and b) after the accelerated aging process

Regarding the multicomponent formulations, BXT/5 formulation is composed of the active principles IRGASAN DP $300 \circledR$ and ACTICIDE SR $1288 \AA$, and it was tested against all microorganisms listed in Table 5 to evaluate its antimicrobial efficiency. After the biological tests, the treatment showed great efficiency against the bacteria Staphylococcus aureus and the two types of algae, Scenedesmus vaculatus and Stichococcus bacillaris, with growth indexes of 0 for all dosages, as seen in Figure 7. In these cases, no biological growth occurred on the surfaces, and inhibition halos surrounding the samples were observed. However, the formulation did not present antimicrobial activity against Escherichia coli at any dose. This may be due to the low content of ACTICIDE SR $1288 ®$ in the mixtures; BXT, which had the same active principle but in greater amounts, presented highly antimicrobial behaviour. The growth indexes against this microorganism with BXT/5 were 2 in all cases (see Figure 7). The treatment was also inefficient against the fungus Aspergillus niger, reaching only an acceptable level of activity, with a growth index of 1 , at the highest dose $(0.4 \%)$. At all other doses, the growth index was 2 , with no inhibition of biological growth. The unsatisfactory behaviour of the treatment against Escherichia coli and Aspergillus niger justified the discarding of the treatment without accelerated aging.

452 Figure 7. Effectiveness of concrete made with BXT/5 formulation against different 453 microorganisms: a) before and b) after the accelerated aging process 
Finally, concrete samples made with PL-UV-H-2B formulation were analysed. Figure 8a shows the results of microorganism colonisation after the incubation period of the formulation. As noted in section 3.1, because the formulation is expected to present algaecide, bactericide, and fungicide activity, the compound was tested against all microorganisms listed in Table 5 to evaluate its antimicrobial efficiency. The concrete samples present efficiency against all microorganisms evaluated at all dosages; it prevents biological growth on the surface and, in most cases, forms an inhibition halo surrounding the sample. With both bacteria and algae, the concrete shows high antimicrobial activity with growth indexes of 0 in all cases. With Aspergillus niger, higher formulation dosages of 0.2 and $0.3 \%$ are required to obtain the same effect, as the lowest dose of $0.1 \%$ presents a growth index of 1 with no inhibition halo surrounding the sample surface. The growth indexes for the reference samples against the different microorganisms vary from 1 to 2 .

Figure 8. Effectiveness of concrete made with PL-UV-H-2B formulation against different microorganisms: a) before and b) after the accelerated aging process

According to the results of the initial antimicrobial test, the formulation PL-UV-H-2B was considered valid and the samples were then subjected to the accelerated aging test. A second antimicrobial test was conducted; images of the microbiological cultures are shown in Figure 8b. The antimicrobial activities against both bacteria and algae prevail after the aging process, although larger inhibition halos surrounding the samples are observed at higher dosages of the formulation. The growth index in all cases is zero. For the efficiency against fungal growth, a slight loss of the antimicrobial activity is perceived because the inhibition halo is not formed 
at any dosage. However, no biological growth occurs on the concrete samples; the growth

\section{Conclusions}

482 Fifteen biocide formulations were studied during this campaign to assess their biocide effects when incorporated into concrete. These formulations were elaborated from different commercially available antimicrobial products that were chosen for cost-effectiveness, nontoxicity, and capacity as disinfectants in other applications, such as floor and wall coverings.

The biocide formulations were composed of one (monocomponent) or more antimicrobial products (multicomponent) as well as incorporating different additives in some cases.

A three-phase process was performed to evaluate the physical properties, release of active and antimicrobial properties of the concrete samples incorporating the different formulations. The study showed that monocomponent formulations were insufficient to inhibit biological growth in concrete without either significant detriment to the mechanical properties of the material or losing efficient biostatic activity after a short period. To obtain a long-lasting effect against a wide spectrum of microorganisms, the use of multicomponent formulations was necessary.

The use of existing commercial products such as Vanquish $100 \AA$, Densil $\mathrm{P} 囚$, and BC 98-56 presented significant reductions in the mechanical resistances of concrete, typically with influences during the hardening process. The formulations BXT/AB and BXT/11, which incorporated IRGASAN DP 300®, also showed decreases in the strengths of the concrete. This active principle, in certain compositions, caused a decrease in density through air entrapment in the concrete mix. Some multicomponent formulations, such as BXT/12C, $\mathrm{BXT} / 10 \mathrm{P}$, and BXT/1, also presented poor performance regarding mechanical properties. The 
503 effect of the biostatic agents in the cement hydration process was the main reason for the

mechanical degradation of the concrete, especially at low ages.

Many of the formulations affected significantly the physical and mechanical properties of the concrete samples, thus presenting lower mechanical performances. Two different behaviour were observed. According to the results obtained, some formulations presented an interaction of the actives with the cement hydration process. The low mechanical performance of the samples at early ages may be related with the retardation of the hydration reactions. Furthermore, air-entrapping was also observed. The formulations Vanquish 100®, Densil P®, and $\mathrm{BC}$ 98-56, as well as BXT/AB and BXT/11, which incorporated IRGASAN DP 300®, were discarded from the evaluation process. aging, the activity against the fungus was not maintained. The multicomponent formulation BXT/5 showed a high antimicrobial efficiency against both algae species and the bacteria Staphylococcus aureus. Despite these results, the treatment did not present any biocide effect 526 against Escherichia coli and Aspergillus niger.

The addition of the chemicals Biopol D212® and Vantocil IB $®$ did not affect the strengths of the concrete mixtures. However, when submitted to release tests, the modified samples presented high solubility in water. This behaviour implied a rapid loss of antimicrobial activity, which would compromise the duration of protection.

In the microbiological tests, the chemicals ACTICIDE MBP® and P 24-81 presented poor results with almost no inhibition of biological growth. BXT offered good results against both types of bacteria and the tested fungus before the accelerated aging process. However, after 
Among all the formulations evaluated, the formulation PL-UV-H-2B was the only one to succeed in all the evaluation process. This multicomponent formulation, when mixed with concrete, did not affect the physical or mechanical properties of the material. Only slight reductions in density, compressive strength, and flexural strength were observed in comparison with those of the reference samples, although the reductions were not significant.

Concerning the release tests, the quantity of active released by this formulation was very low. The quantities released are approximately four orders of magnitude below the amount that may be considered toxic for humans. This result also indicates a greater duration of the biostatic effect of the treatment.

539 Moreover, concrete samples fabricated with PL-UV-H-2B formulation demonstrated high 540 effectiveness in antimicrobial tests against algae, fungi, and bacteria, both before and after 541 accelerated aging processes. The compound prevented biological growth in concrete, and in 542 most cases formed inhibition halos surrounding the samples.

\section{Acknowledgements}

545 The authors acknowledge the economic support provided by the Spanish Ministry of 546 Economy and Competitiveness through Project BIA2013-49106-C2-1-R. Furthermore, the 547 authors wish to thank the company BASF Construction Chemicals for the help provided to the 548 development of this work.

550 References

551 AENOR, 2009a. UNE-EN 12390-2:2009 Testing hardened concrete - Part 2: Making and 552 curing specimens for strength tests 
AENOR, 2009b. UNE-EN 12390-3:2009 Testing hardened concrete - Part 3: Compressive

strength of test specimens

AENOR, 2009c. UNE-EN 12390-5:2009 Testing hardened concrete - Part 5: Flexural strength of test specimens

AENOR, 2010. prEN 16105:2010 Paints and varnishes - Leaching of substances from coatings - Laboratory immersion method

AENOR, 2014. UNE-EN ISO 4892-2:2014 Plastics - Methods of exposure to laboratory light sources - Part 2: Xenon-arc lamps

Aguado, A., Segura, I., Vaquero, J.M., Servos, F., 2014. Additive to inhibit biological growth in concrete structures and use, Spanish Patent reference number P201431036 (under review). Alum, A., Rashid, A., Mobasher, B., Abbaszadegan, M., 2008. Cement-based biocide coatings for controlling algal growth in water distribution canals. Cement \& Concrete Composites, 30: 839-847.

Andrewartha, J.M., Sargison, J.E., and Perkins, K.J., 2007. The effect of Gomphonema and filamentous algae streamers on hydroelectric canal capacity and turbulent boundary layer structure. $16^{\text {th }}$ Australasian Fluid Mechanics Conference.

Chambers, L.D., Stokes, K.R., Walsh, F.C., and Wood, R.J.K., 2006. Modern approaches to marine antifouling coatings. Surface and Coatings Technology 201: 3642-3652.

De Muynck, W., Maury Ramirez, A., De Belie, N., 2009. Evaluation of strategies to prevent 572 algal fouling on white architectural and cellular concrete. International Biodeterioration \& 573 Biodegradation, 63: 679-689.

574 Eyssautier-Chuine, S., Vaillant-Gaveau, N., Gommeaux, M., Thomachot-Schneider, C., 575 Pleck, J., Fronteau, G., 2015. Efficacy of different chemical mixtures against green algal 576 growth on limestone: A case study with Chlorella vulgaris. International Biodeterioration \& 577 Biodegradation, 103: 59-68. 
578 Giannantonio, D.J., Kurth, J.C., Kurtis, K.E., and Sobecky, P. A., 2009. Effects of concrete 579 properties and nutrients on fungal colonization and fouling. International Biodeterioration and Biodegradation, 63: 252-259.

ISO, 2005 ISO 1920-2:2005. Testing of concrete - Part 2: Properties of fresh concrete.

Lancar, L., and Krake, K., 2002. Aquatic Weeds and their Management. International Commission on Irrigation and Drainage.

Malagodi, M., Nugari, M.P., Altieri, A., Lonati, G., 2000. Effects of combined application of biocides and protectives. In: Fassina, V. (Ed.), $9^{\text {th }}$ International Congress on Deterioration and Conservation of Stone. Elsevier, Amsterdam, the Netherlands, 225-233.

Moreau, C., Vergès-Belmin, V., Leroux, L., Orial, G., Fronteau, G., Barbin, V., 2008. Waterrepellent and biocide treatments: assessment of the potential combinations. Journal of Cultural Heritage, 9: 394-400.

Nugari, M.P., Salvadori, O., 2003. Biocides and treatment of stone: limitations and future prospects. In: Koestler, R.J., Koestler, V.H., Charola, E.A.E., Nieto-Fernandez, F.E. (Eds.), Art, Biology and Conservation: Biodeterioration of Works of Art. The Metropolitan Museum of Art, New York, USA, 519-535.

Nugari, M.P., Pietrini, A.M., Caneva, G., Imperi, F., Visca, P., 2009. Biodeterioration of mural paintings in a rocky habitat: the Crypt of the Original Sin (Matera, Italy). International Biodeterioration \& Biodegradation, 63: 705-711.

597 Perkins, K. J., Sargison, J., and Hallegraeff, G. M., 2009. Diatom fouling problems in a 598 Tasmanian hydro canal, including the description of Gomphonema Tarraleahae sp. nov. 599 Diatom Research, 24 (2): 377-391.

600 Urzì, C., De Leo, F., 2007. Evaluation of the efficiency of water-repellent and biocide 601 compounds against microbial colonisation of mortars. International Biodeterioration \& 602 Biodegradation, 60: 25-34. 
603 Vaquero, J. M., 2013. Microorganism-concrete interactions: evaluation methods and possible 1

2604 solutions. PhD Thesis. Department of Construction Engineering, Universitat Politècnica de

5605 Catalunya - Barcelona Tech. http://www.tdx.cat/handle/10803/116930

606 Wei, S., Jiang, Z., Liu, H., Zhou, D., and Sanchez-Silva, M., 2013. Microbiologically induced 907 deterioration of concrete - A Review. Brazilian Journal of Microbiology, 44(4): 1001-1007. 
Table 1. Concrete dosages for reference and biocide mixtures

\begin{tabular}{|l|l|}
\hline Compound & Dosage $\left(\mathbf{k g} / \mathbf{m}^{\mathbf{3}}\right)$ \\
\hline Cement & 350 \\
\hline Fine aggregate $(0-5 \mathrm{~mm})$ & 1074 \\
\hline Coarse aggregate $(5-12 \mathrm{~mm})$ & 724 \\
\hline Plasticiser & $3.5(1 \%)$ \\
\hline Water & 244 \\
\hline
\end{tabular}


Table 2. General information on the different antimicrobial products evaluated

\begin{tabular}{|c|c|c|c|c|}
\hline Number & Active & $\begin{array}{c}\text { Commercial } \\
\text { name }\end{array}$ & Effect & $\begin{array}{c}\text { Physical } \\
\text { state }\end{array}$ \\
\hline 1 & $\begin{array}{l}\text { bis(2-pyridylthio)zinc 1,1'- } \\
\text { dioxide (Zinc pyrithione 10\%) }\end{array}$ & $\begin{array}{c}\text { ACTICIDE SR } \\
1288 \AA\end{array}$ & $\begin{array}{l}\text { Fungicide and } \\
\text { bactericide }\end{array}$ & Liquid \\
\hline 2 & $\begin{array}{c}\text { 1,2,3,6-Tetrahydro-N- } \\
\text { (trichloromethylthio)phthalimide }\end{array}$ & BIOPOL D 212® & Fungicide & Powder \\
\hline 3 & $\begin{array}{c}\text { Dithio-2,2'- } \\
\text { bis(benzmethylamide) }\end{array}$ & DENSIL P® & $\begin{array}{c}\text { Fungicide and } \\
\text { bactericide }\end{array}$ & Liquid \\
\hline 4 & $\begin{array}{l}\text { 2-pyridinethiol-1- } \mathrm{NaO}+1,2 \text { - } \\
\text { benzisothiazole-3 }(2 \mathrm{H}) \text {-one }\end{array}$ & P 24-81 & $\begin{array}{c}\text { Fungicide and } \\
\text { bactericide }\end{array}$ & Powder \\
\hline 5 & $\begin{array}{c}\text { bis(2-pyridylthio)zinc 1,1'- } \\
\text { dioxide (Zinc pyrithione 10\%) }\end{array}$ & ВC 98-56 & $\begin{array}{c}\text { Fungicide and } \\
\text { bactericide }\end{array}$ & Powder \\
\hline 6 & $\begin{array}{l}\text { n-Butyl-1,2-benzisothiazolin-3- } \\
\text { one }\end{array}$ & VANQUISH 100® & $\begin{array}{l}\text { Fungicide, } \\
\text { bactericide } \\
\text { and } \\
\text { algaecide }\end{array}$ & Liquid \\
\hline 7 & $\begin{array}{l}\text { Poly(hexamethylene biguanide) } \\
\text { hydrochloride }\end{array}$ & VANTOCIL IB® & Bactericide & Liquid \\
\hline 8 & $\begin{array}{c}\text { 2-octyl-2H-isothiazol-3-one }+ \\
\text { Terbutryn }\end{array}$ & $\begin{array}{c}\text { ACTICIDE SR } \\
1453 \circledR\end{array}$ & $\begin{array}{l}\text { Algaecide and } \\
\text { fungicide }\end{array}$ & Powder \\
\hline 9 & $\begin{array}{c}\text { n-Tert-butyl-N-cyclopropyl-6- } \\
\text { (methylthio)-1,3,5-triazine-2,4- } \\
\text { diamine }+2 \text { Octyl-2H- } \\
\text { isothiazol-3-one }\end{array}$ & ACTICIDE MBP® & $\begin{array}{l}\text { Bactericide } \\
\text { and fungicide }\end{array}$ & Powder \\
\hline 10 & $\begin{array}{l}\text { 2,4,4'-trichloro-2'-hydroxy- } \\
\text { diphenyl ether }\end{array}$ & $\begin{array}{l}\text { IRGASAN DP } \\
300 \circledR\end{array}$ & $\begin{array}{l}\text { Bactericide } \\
\text { and fungicide }\end{array}$ & Powder \\
\hline
\end{tabular}


Table 3. General information on the biocide formulations

\begin{tabular}{|c|c|c|c|}
\hline \multicolumn{2}{|c|}{ Formulation name } & Active number & Additives \\
\hline \multirow{10}{*}{ 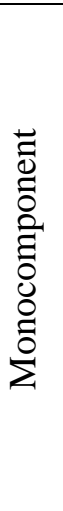 } & BXT & 1 & Calcium filler (20\%) \\
\hline & BIOPOL D212 & 2 & - \\
\hline & DENSIL P & 3 & - \\
\hline & P24-81 & 4 & - \\
\hline & BC 98-56 & 5 & - \\
\hline & VANQUISH 100 & 6 & - \\
\hline & VANTOCIL IB & 7 & - \\
\hline & ACTICIDE MBP & 9 & - \\
\hline & $\mathrm{BXT} / 11$ & 10 & PG $(59.7 \%)$, TIBP $(0.3 \%)$, water $(15 \%)$ \\
\hline & $\mathrm{BXT} / \mathrm{AB}$ & 10 & PG $(74.44 \%)$, TIBP $(0.45 \%)$, BUBLEX® $(0.11)$ \\
\hline \multirow{5}{*}{ 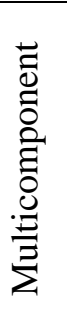 } & $\mathrm{BXT} / 1$ & $1(16 \%), 8(59 \%)$ & MOUSSEX® $(4 \%)$, water $(21 \%)$ \\
\hline & $\mathrm{BXT} / 5$ & $1(8 \%), 10(3.45 \%)$ & $\begin{array}{c}\text { PG (10\%), PEG }(10 \%), \text { TIBP }(0.15 \%), \\
\text { OPTIGEL CR® }(1.5 \%)\end{array}$ \\
\hline & $\mathrm{BXT} / 10 \mathrm{P}$ & $9(15 \%), 10(4 \%)$ & MOUSSEX® $(0.3 \%)$, Calcium filler (80.7) \\
\hline & $\mathrm{BXT} / 12 \mathrm{C}$ & $1(5.12 \%), 10(5 \%)$ & $\begin{array}{c}\text { PG (12.23\%), PEG }(77.34 \%), \text { TIBP }(0.21 \%), \\
\text { BUBLEX® }(0.1 \%)\end{array}$ \\
\hline & PL-UV-H-2B & $8(30 \%), 10(15 \%)$ & MOUSSEX® $(4 \%)$, Calcium filler $(51 \%)$ \\
\hline
\end{tabular}


Table 4. Dosage of the biocide formulations and active contents

\begin{tabular}{|c|c|c|c|c|c|}
\hline \multirow{2}{*}{\multicolumn{2}{|c|}{ Formulation name }} & \multirow{2}{*}{ Dosage (\% odw) } & \multicolumn{3}{|c|}{ Active content $(\mathrm{kg} / \mathrm{m} 3)$} \\
\hline & & & \multirow{2}{*}{$\begin{array}{c}\mathrm{A} \\
0.859\end{array}$} & \multirow{2}{*}{$\begin{array}{l}\mathrm{B} \\
-\end{array}$} & \multirow{2}{*}{$\begin{array}{l}\text { Total } \\
0.859\end{array}$} \\
\hline \multirow{30}{*}{ 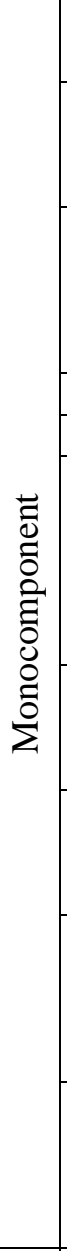 } & \multirow{2}{*}{ BXT } & 0.05 & & & \\
\hline & & 0.15 & 2.578 & - & 2.578 \\
\hline & \multirow{3}{*}{ BIOPOL D212 } & 0.1 & 2.148 & - & 2.148 \\
\hline & & 0.2 & 4.296 & - & 4.296 \\
\hline & & 0.3 & 6.444 & - & 6.444 \\
\hline & \multirow{4}{*}{ DENSIL P } & 0.2 & 4.296 & - & 4.296 \\
\hline & & 0.5 & 10.740 & - & 10.740 \\
\hline & & 1 & 21.480 & - & 21.480 \\
\hline & & 2 & 42.960 & - & 42.960 \\
\hline & P24-81 & 0.3 & 6.444 & - & 6.444 \\
\hline & BC 98-56 & 0.3 & 6.444 & - & 6.444 \\
\hline & \multirow{5}{*}{ VANQUISH 100} & 0.002 & 0.043 & - & 0.043 \\
\hline & & 0.013 & 0.279 & - & 0.279 \\
\hline & & 0.025 & 0.537 & - & 0.537 \\
\hline & & 0.037 & 0.795 & - & 0.795 \\
\hline & & 0.05 & 1.074 & - & 1.074 \\
\hline & \multirow{3}{*}{ VANTOCIL IB } & 0.3 & 6.444 & - & 6.444 \\
\hline & & 0.6 & 12.888 & - & 12.888 \\
\hline & & 1 & 21.480 & - & 21.480 \\
\hline & \multirow{3}{*}{ ACTICIDE MBP } & 0.1 & 2.148 & - & 2.148 \\
\hline & & 0.4 & 8.592 & - & 8.592 \\
\hline & & 0.8 & 17.184 & - & 17.184 \\
\hline & \multirow{4}{*}{ BXT/11 } & 0.15 & 0.806 & - & 0.806 \\
\hline & & 0.18 & 0.967 & - & 0.967 \\
\hline & & 0.2 & 1.074 & - & 1.074 \\
\hline & & 0.22 & 1.181 & - & 1.181 \\
\hline & \multirow{4}{*}{$\mathrm{BXT} / \mathrm{AB}$} & 0.01 & 0.054 & - & 0.054 \\
\hline & & 0.05 & 0.269 & - & 0.269 \\
\hline & & 0.1 & 0.537 & - & 0.537 \\
\hline & & 0.15 & 0.806 & - & 0.806 \\
\hline \multirow{14}{*}{ 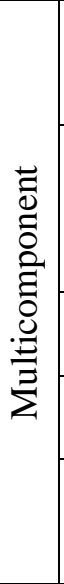 } & \multirow{3}{*}{$\mathrm{BXT} / 1$} & 2.5 & 8.592 & 31.683 & 40.275 \\
\hline & & 3 & 10.310 & 38.020 & 48.330 \\
\hline & & 3.5 & 12.029 & 44.356 & 56.385 \\
\hline & \multirow{4}{*}{$\mathrm{BXT} / 5$} & 0.075 & 0.056 & 0.129 & 0.184 \\
\hline & & 0.15 & 0.111 & 0.258 & 0.369 \\
\hline & & 0.2 & 0.148 & 0.344 & 0.492 \\
\hline & & 0.4 & 0.296 & 0.687 & 0.984 \\
\hline & \multirow{2}{*}{$\mathrm{BXT} / 10 \mathrm{P}$} & 0.8 & 0.687 & 2.578 & 3.265 \\
\hline & & 1 & 0.859 & 3.222 & 4.081 \\
\hline & \multirow{2}{*}{$\mathrm{BXT} / 12 \mathrm{C}$} & 0.1 & 0.110 & 0.107 & 0.217 \\
\hline & & 0.6 & 0.660 & 0.644 & 1.304 \\
\hline & \multirow{3}{*}{ PL-UV-H-2B } & 0.15 & 0.483 & \begin{tabular}{|l|}
0.967 \\
\end{tabular} & 1.450 \\
\hline & & 0.2 & 0.644 & 1.289 & 1.933 \\
\hline & & 0.3 & 0.967 & 1.933 & 2.900 \\
\hline
\end{tabular}


Table 5. Microorganisms used for to evaluate antimicrobial properties and characteristics of incubation periods thereof

\begin{tabular}{|c|c|c|c|c|c|}
\hline \multirow[b]{2}{*}{$\begin{array}{c}\text { Type of } \\
\text { microorganism }\end{array}$} & \multirow[b]{2}{*}{ Microorganism } & \multirow[b]{2}{*}{$\begin{array}{l}\text { Reference } \\
\text { code }\end{array}$} & \multicolumn{3}{|c|}{ Incubation period } \\
\hline & & & Agar type & $\begin{array}{l}\text { Temperature } \\
\left({ }^{\circ} \mathrm{C}\right)\end{array}$ & $\begin{array}{l}\text { Time } \\
\text { (days) }\end{array}$ \\
\hline Fungus & $\begin{array}{c}\text { Aspergillus } \\
\text { niger }\end{array}$ & ATCC 6275 & $\begin{array}{c}\text { Malt extract } \\
\text { agar }\end{array}$ & $25 \pm 2$ & $5-7$ \\
\hline Bacteria & $\begin{array}{c}\text { Staphylococcus } \\
\text { aureus }\end{array}$ & ATCC 6538P & \multirow{2}{*}{$\begin{array}{l}\text { Nutrient } \\
\text { agar }\end{array}$} & $30 \pm 2$ & 2 \\
\hline Bacteria & Escherichia coli & ATCC 8739 & & $30 \pm 2$ & 2 \\
\hline Algae & $\begin{array}{l}\text { Scenedesmus } \\
\text { vaculatus }\end{array}$ & SAG 211-8b & \multirow{2}{*}{$\begin{array}{l}\text { Kuhl } \\
\text { solution }\end{array}$} & $20 \pm 2$ & 21 \\
\hline Algae & $\begin{array}{c}\text { Stichococcus } \\
\text { bacillaris }\end{array}$ & SAG 379-1a & & $20 \pm 2$ & 21 \\
\hline
\end{tabular}


Table 6. Failure phases and qualification of each formulation during the experimental campaign

\begin{tabular}{|c|c|c|}
\hline \multicolumn{2}{|r|}{ Formulation } & Failure phase \\
\hline \multirow{10}{*}{ 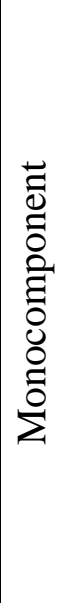 } & $\mathrm{BXT} / \mathrm{AB}$ & Physical properties \\
\hline & $\mathrm{BXT} / 11$ & Physical properties \\
\hline & ACTICIDE MBP & Antimicrobial properties (before aging process) \\
\hline & BIOPOL D212 & Releasing test \\
\hline & VANTOCIL IB & Releasing test \\
\hline & VANQUISH 100 & Physical properties \\
\hline & DENSIL P & Physical properties \\
\hline & P24-81 & Antimicrobial properties (before aging process) \\
\hline & BC 98-56 & Physical properties \\
\hline & BXT & Antimicrobial properties (after aging process) \\
\hline \multirow{5}{*}{ 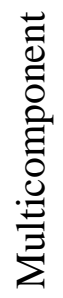 } & $\mathrm{BXT} / 12 \mathrm{C}$ & Physical properties \\
\hline & $\mathrm{BXT} / 10 \mathrm{P}$ & Physical properties \\
\hline & BXT/1 & Physical properties \\
\hline & $\mathrm{BXT} / 5$ & Antimicrobial properties (before aging process) \\
\hline & PL-UV-H-2B & None \\
\hline
\end{tabular}


Table 7. Mechanical properties of the monocomponent formulations failing first phase tests

\begin{tabular}{|c|c|c|c|c|c|c|c|}
\hline \multirow{3}{*}{$\begin{array}{c}\text { Formulation } \\
\text { name }\end{array}$} & \multirow{3}{*}{$\begin{array}{c}\text { Dosage } \\
(\% \\
\text { odw) }\end{array}$} & \multirow{3}{*}{$\begin{array}{l}\text { Flow } \\
(\mathbf{m m})\end{array}$} & \multirow{3}{*}{$\begin{array}{c}\text { Fresh } \\
\text { density } \\
\left(\mathbf{k g} / \mathrm{m}^{3}\right)\end{array}$} & \multicolumn{4}{|c|}{ Mechanical properties (MPa) } \\
\hline & & & & \multicolumn{2}{|c|}{$\begin{array}{c}\text { Compressive } \\
\text { strength }\end{array}$} & \multicolumn{2}{|c|}{$\begin{array}{l}\text { Flexural } \\
\text { strength }\end{array}$} \\
\hline & & & & $1 \mathrm{~d}$ & 28d & 1d & 28d \\
\hline \multirow{5}{*}{ DENSIL P } & 0 & 154 & 2450 & 19.1 & 47.8 & 4.8 & 8.2 \\
\hline & 0.2 & 154 & 2435 & 19.3 & 48.3 & 4.6 & 9.4 \\
\hline & 0.5 & 155 & 2435 & 8.5 & 41.1 & 2.2 & 7.2 \\
\hline & 1.0 & 155 & 2435 & 4.4 & 42.1 & 1.2 & 8.3 \\
\hline & 2.0 & 159 & 2422 & n.d. & 34.2 & n.d. & 7.3 \\
\hline \multirow{2}{*}{ BC $98-56$} & 0 & 150 & 2432 & 12.8 & 33.5 & 3.5 & 6.8 \\
\hline & 0.3 & 135 & 2465 & n.d. & 36.6 & n.d. & 7.6 \\
\hline \multirow{6}{*}{ VANQUISH 100} & 0 & 155 & 2450 & 15.4 & 33.6 & 3.3 & 6.5 \\
\hline & 0.002 & 152 & 2392 & 14.2 & 33.1 & 2.9 & 6.1 \\
\hline & 0.013 & 152 & 2401 & 13.1 & 29.2 & 2.8 & 5.6 \\
\hline & 0.025 & 153 & 2417 & 13.4 & 27.4 & 3.0 & 5.5 \\
\hline & 0.037 & 156 & 2439 & 12.8 & 30.9 & 3.0 & 5.4 \\
\hline & 0.050 & 150 & 2427 & 12.8 & 27.4 & 2.5 & 5.8 \\
\hline \multirow{5}{*}{ BXT/11 } & 0 & 117 & 2389 & 15.5 & 35.1 & 3.2 & 5.6 \\
\hline & 0.15 & 118 & 2005 & 5.3 & 16.0 & 2.1 & 3.3 \\
\hline & 0.18 & 122 & 2004 & 7.2 & 21.4 & 2.5 & 5.2 \\
\hline & 0.20 & 121 & 2122 & 6.9 & 20.9 & 2.7 & 5.3 \\
\hline & 0.22 & 127 & 2174 & 9.6 & 24.3 & 2.4 & 5.8 \\
\hline \multirow{5}{*}{$\mathrm{BXT} / \mathrm{AB}$} & 0 & 117 & 2389 & 15.5 & 35.1 & 3.2 & 5.6 \\
\hline & 0.01 & 120 & 2420 & 15.1 & 29.9 & 2.6 & 5.4 \\
\hline & 0.05 & 125 & 2395 & 14.8 & 34.3 & 2.8 & 5.4 \\
\hline & 0.10 & 128 & 2467 & 13.0 & 31.8 & 2.3 & 5.0 \\
\hline & 0.15 & 124 & 2397 & 11.9 & 29.8 & 2.1 & 4.9 \\
\hline
\end{tabular}


Table 8. Mechanical properties of the multicomponent formulations

\begin{tabular}{|c|c|c|c|c|c|c|c|}
\hline \multirow{3}{*}{$\begin{array}{c}\text { Formulation } \\
\text { name }\end{array}$} & \multirow{3}{*}{$\begin{array}{c}\text { Dosage } \\
(\% \\
\text { odw) }\end{array}$} & \multirow{3}{*}{$\begin{array}{l}\text { Flow } \\
(\mathbf{m m})\end{array}$} & \multirow{3}{*}{$\begin{array}{c}\text { Fresh } \\
\text { density } \\
\left(\mathbf{k g} / \mathbf{m}^{3}\right)\end{array}$} & \multicolumn{4}{|c|}{ Mechanical properties (MPa) } \\
\hline & & & & \multicolumn{2}{|c|}{$\begin{array}{l}\text { Compressive } \\
\text { strength }\end{array}$} & \multicolumn{2}{|c|}{$\begin{array}{l}\text { Flexural } \\
\text { strength }\end{array}$} \\
\hline & & & & $1 \mathrm{~d}$ & 28d & 1d & 28d \\
\hline \multirow{4}{*}{$\mathrm{BXT} / 1$} & 0 & 157 & 2426 & 12.5 & 36.7 & 3.7 & 7.5 \\
\hline & 0.4 & 150 & 2465 & n.d. & 34.0 & n.d. & 6.7 \\
\hline & 0.45 & 153 & 2439 & n.d. & 31.2 & n.d. & 6.5 \\
\hline & 0.5 & 149 & 2468 & n.d. & 34.3 & n.d. & 6.3 \\
\hline \multirow{5}{*}{$\mathrm{BXT} / 5$} & 0 & 165 & 2343 & 15.8 & 42.3 & 4.8 & 8.7 \\
\hline & 0.08 & 170 & 2337 & 14.9 & 40.5 & 4.3 & 8.1 \\
\hline & 0.15 & 167 & 2381 & 15.1 & 40.0 & 3.8 & 8.4 \\
\hline & 0.2 & 165 & 2330 & 14.5 & 39.0 & 3.5 & 7.9 \\
\hline & 0.4 & 168 & 2327 & 14.0 & 39.0 & 3.3 & 7.7 \\
\hline \multirow{3}{*}{$\mathrm{BXT} / 10 \mathrm{P}$} & 0 & 125 & 2473 & 19.1 & 35.0 & 4.8 & 7.2 \\
\hline & 0.8 & 117 & 2266 & 10.3 & 30.6 & 2.8 & 6.1 \\
\hline & 1 & 120 & 2200 & 8.2 & 29.0 & 2.5 & 6.0 \\
\hline \multirow{3}{*}{$\mathrm{BXT} / 12 \mathrm{C}$} & 0 & 117 & 2389 & 12.8 & 33.5 & 3.5 & 6.8 \\
\hline & 0.6 & 120 & 2420 & 8.1 & 28.4 & 2.8 & 5.6 \\
\hline & 1 & 125 & 2395 & 6.2 & 22.7 & 2.3 & 4.4 \\
\hline \multirow{4}{*}{ PL-UV-H-2B } & 0 & 148 & 2523 & 14.3 & 37.1 & 4.0 & 9.4 \\
\hline & 0.15 & 152 & 2501 & 12.7 & 36.9 & 3.5 & 8.6 \\
\hline & 0.2 & 145 & 2479 & 11.3 & 35.7 & 2.8 & 8.2 \\
\hline & 0.3 & 150 & 2484 & 14.0 & 34.9 & 3.2 & 8.5 \\
\hline
\end{tabular}


Figure 1. Flowchart of the experimental campaign

Figure 2. Releasing curves of the active from concrete fabricated with monocomponent formulations: a) ACTICIDE MBP, b) BIOPOL D212, c) VANTOCIL IB, d) P24-81, and e) BXT

Figure 3. Releasing curves of the active from concrete fabricated with PL-UV-H-2B formulation

Figure 4. Effectiveness of concrete made with Acticide MBP formulation against different microorganisms

Figure 5. Effectiveness of concrete made with $\mathrm{P}$ 24-81 formulation against different microorganisms

Figure 6. Effectiveness of concrete made with BXT formulation against different microorganisms: a) before and b) after the accelerated aging process Figure 7. Effectiveness of concrete made with BXT/5 formulation against different microorganisms: a) before and b) after the accelerated aging process Figure 8. Effectiveness of concrete made with PL-UV-H-2B formulation against different microorganisms: a) before and b) after the accelerated aging process 


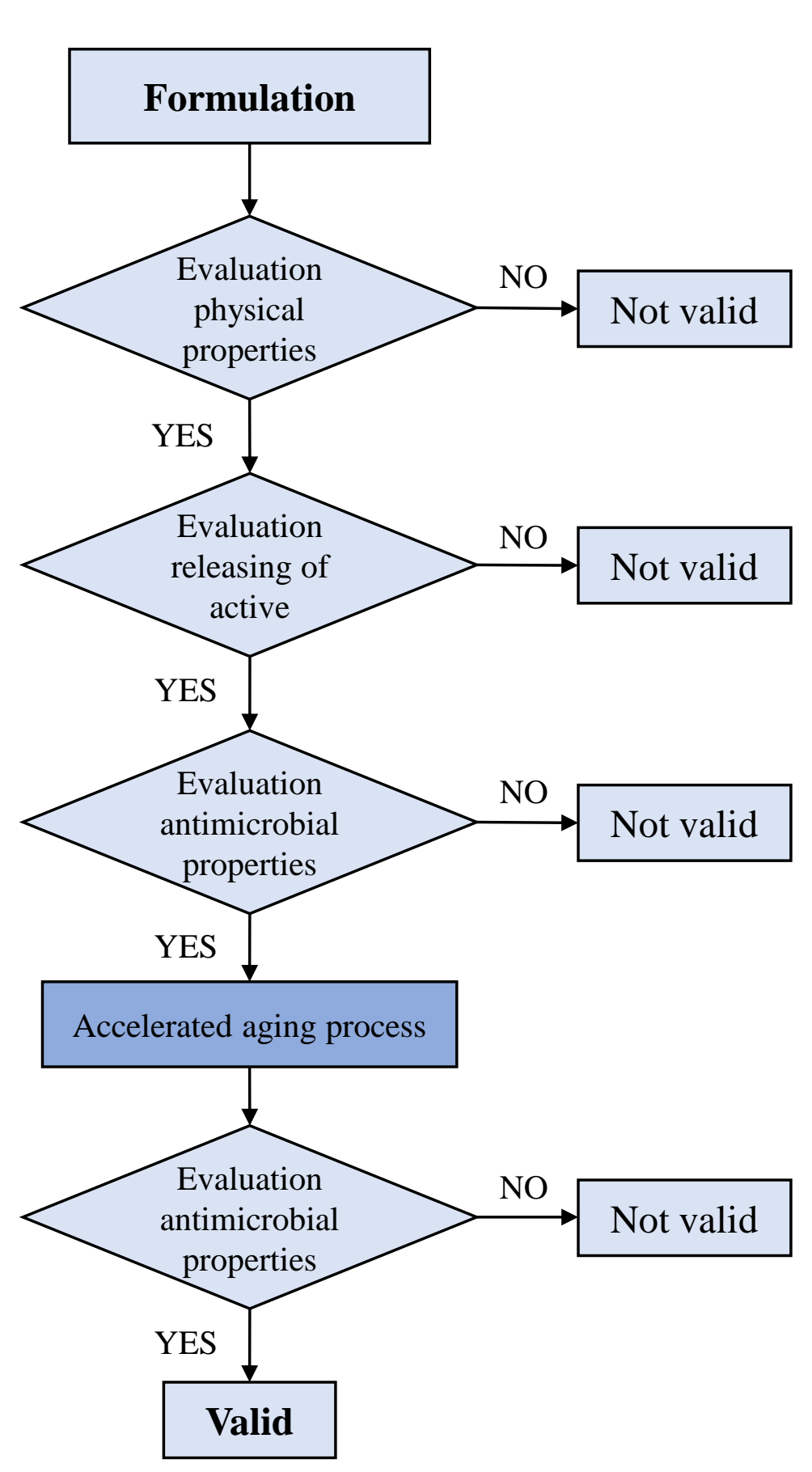



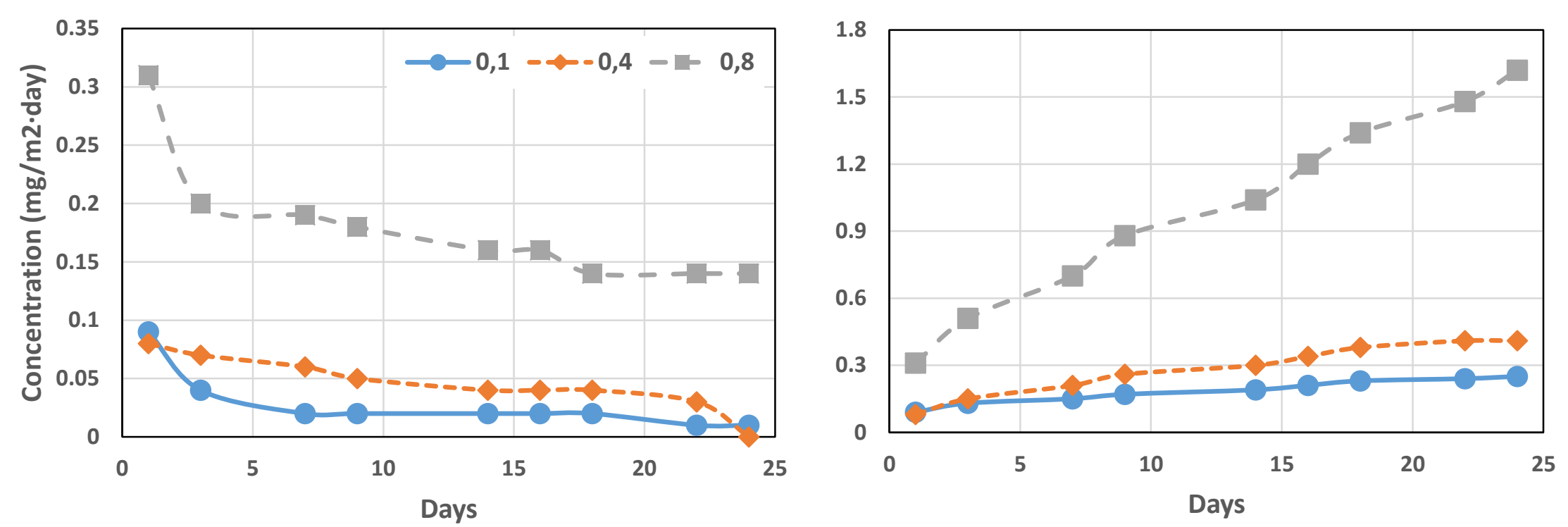

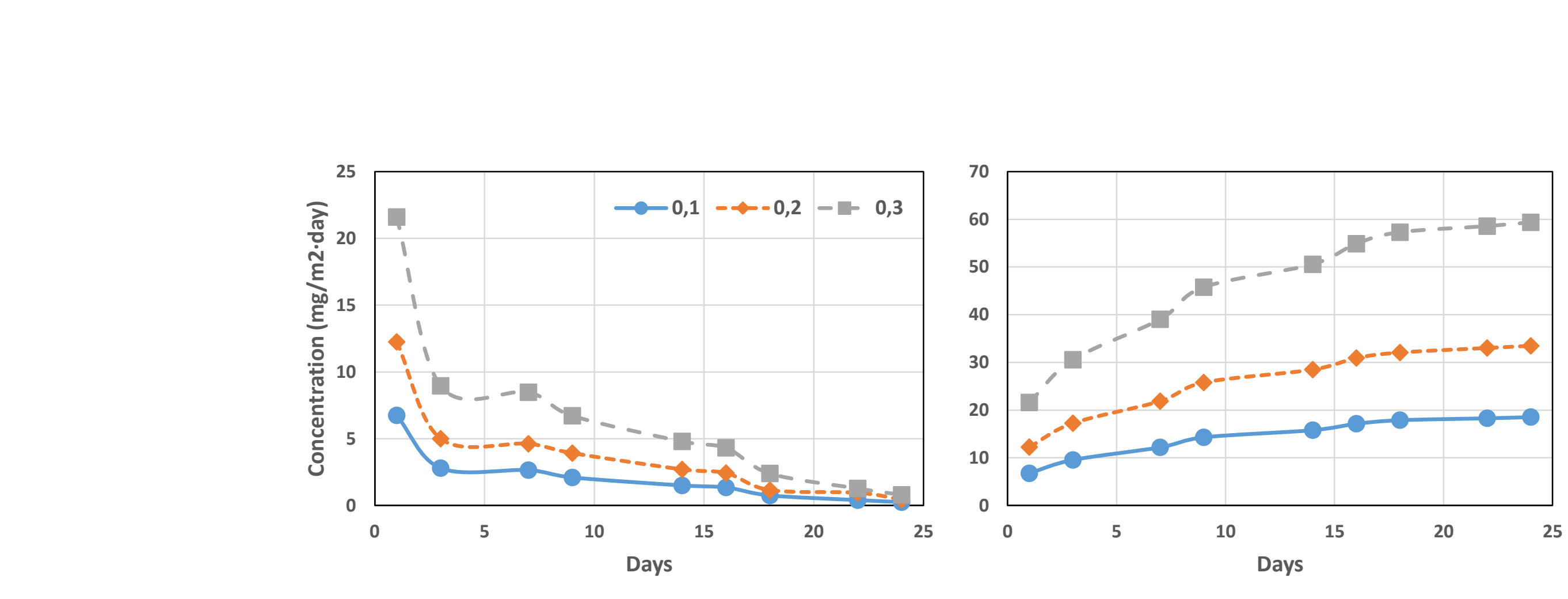

. 

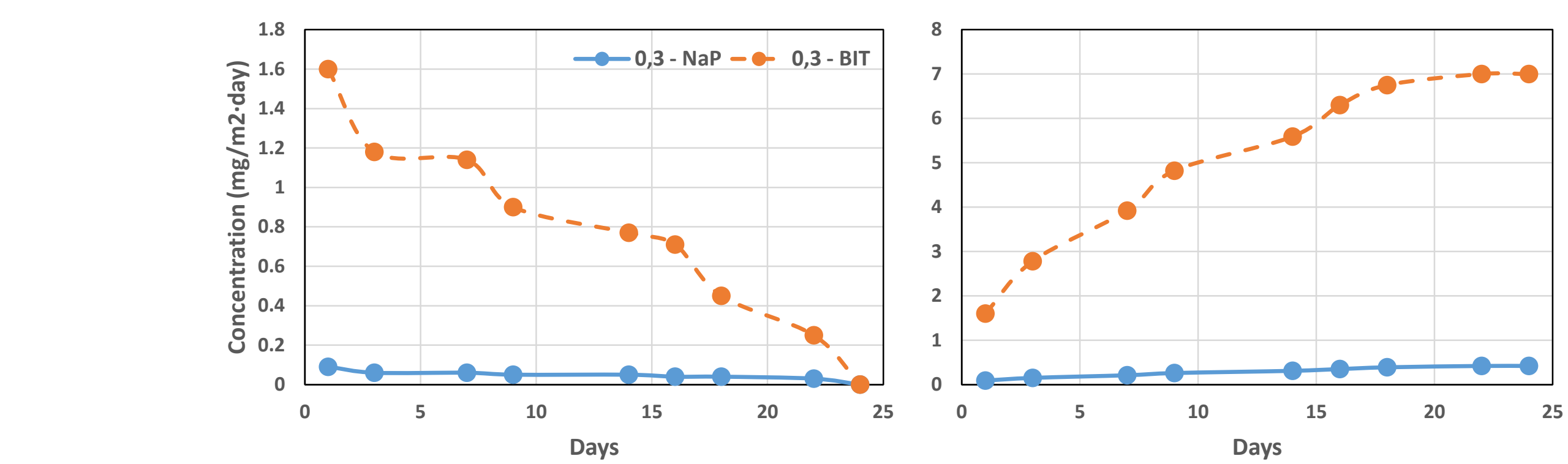

$$
25
$$



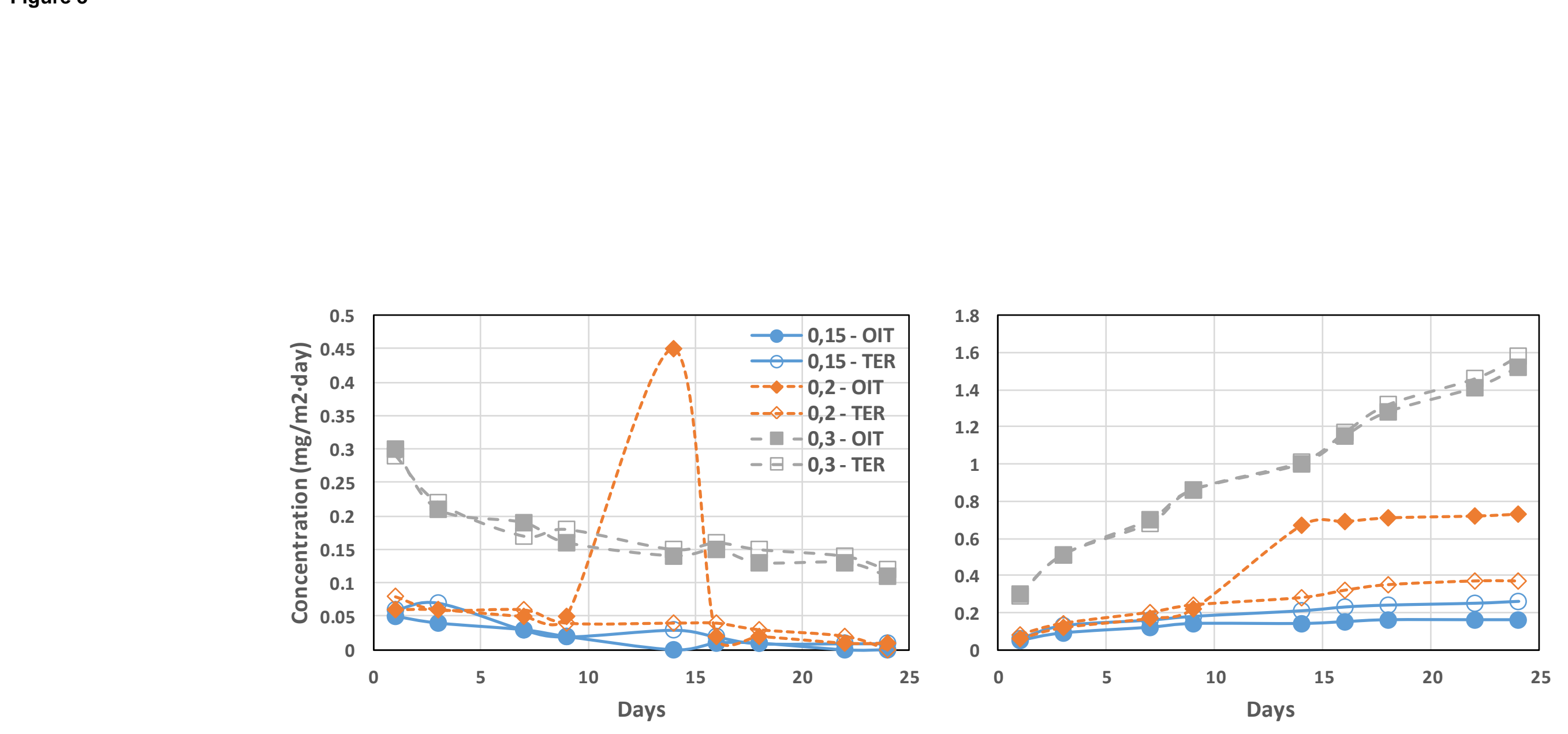

\section{Figur}

Days

Days

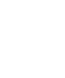




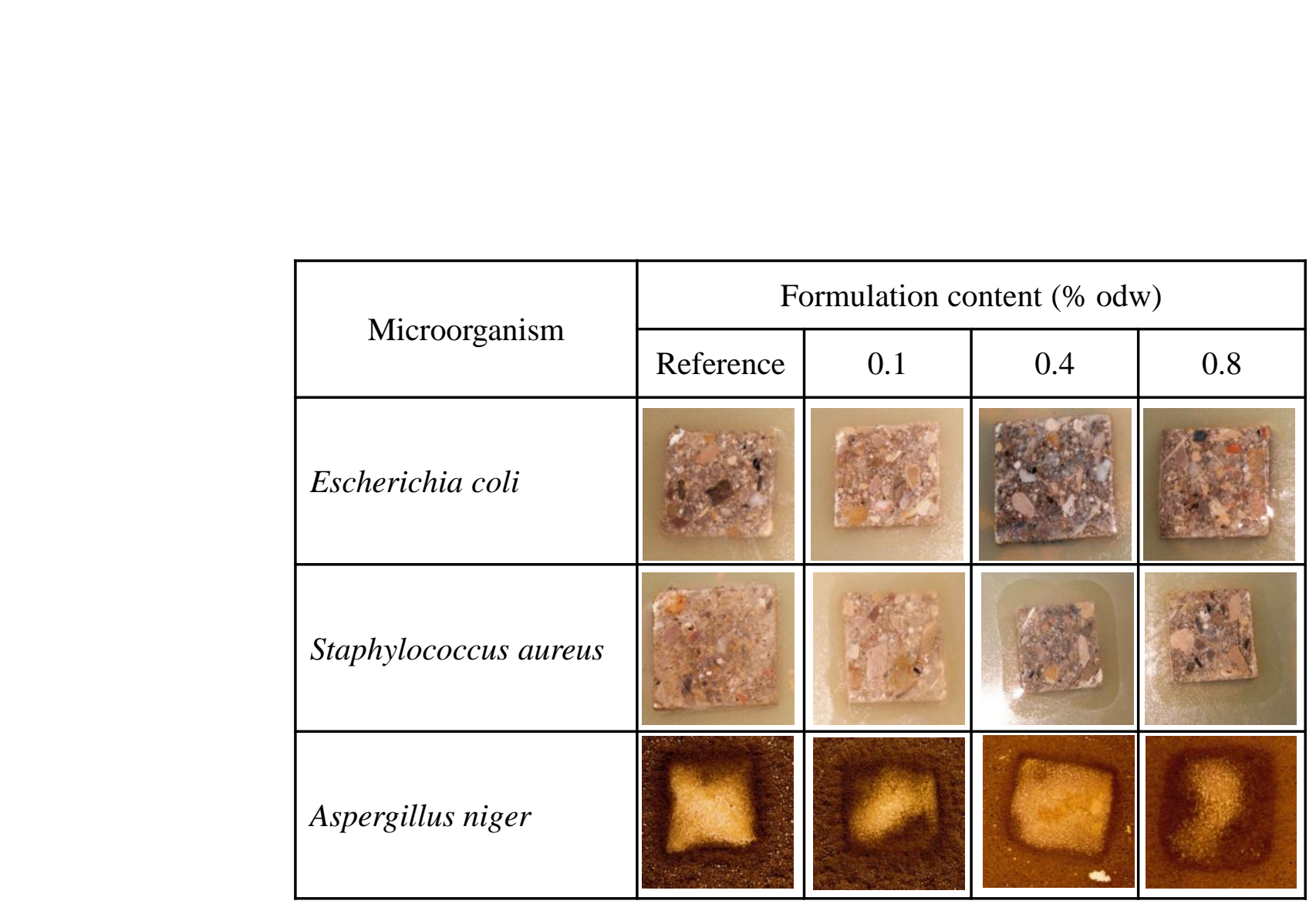




\begin{tabular}{|l|r|c|}
\hline \multirow{2}{*}{ Microorganism } & \multicolumn{2}{|c|}{$\begin{array}{c}\text { Formulation content } \\
\text { (\% odw) }\end{array}$} \\
\cline { 2 - 3 } & Reference & 0.3 \\
\hline \multirow{4}{*}{ Escherichia coli } & & \\
\hline & & \\
Staphylococcus aureus & & \\
& & \\
\hline & & \\
\hline & & \\
Aspergillus niger & & \\
\hline
\end{tabular}


a)

\begin{tabular}{|l|c|c|c|}
\hline \multirow{2}{*}{ Microorganism } & \multicolumn{3}{|c|}{ Formulation content (\% odw) } \\
\cline { 2 - 4 } & Reference & 0.05 & 0.15 \\
\hline \multirow{2}{*}{ Escherichia coli } & & & \\
\hline Staphylococcus aureus & & & \\
& & & \\
\hline Aspergillus niger & & & \\
\hline & & & \\
\hline
\end{tabular}

b)

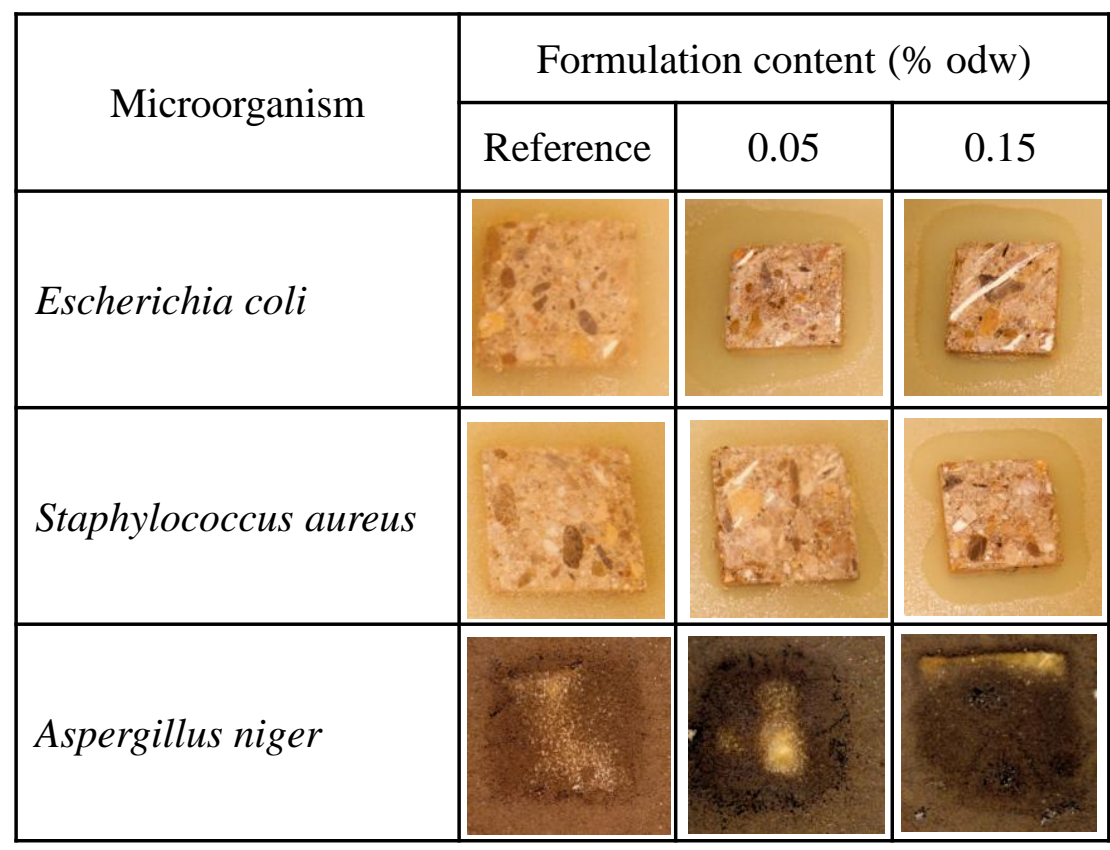




\begin{tabular}{|c|c|c|c|c|c|}
\hline \multirow{2}{*}{ Microorganism } & \multicolumn{5}{|c|}{ Formulation content ( $\%$ odw) } \\
\hline & Reference & 0.075 & 0.15 & 0.2 & 0.4 \\
\hline Escherichia coli & & & & & \\
\hline $\begin{array}{l}\text { Staphylococcus } \\
\text { aureus }\end{array}$ & & & & & \\
\hline Aspergillus niger & & & & & \\
\hline $\begin{array}{l}\text { Stichococcus } \\
\text { bacillaris } \\
\text { Scenedesmus } \\
\text { vaculatus }\end{array}$ & sil. & & & & \\
\hline
\end{tabular}


a)

\begin{tabular}{|l|l|l|l|l|}
\hline \multirow{2}{*}{ Microorganism } & \multicolumn{4}{|c|}{ Formulation content (\% odw) } \\
\cline { 2 - 5 } & Reference & 0.15 & 0.2 & 0.3 \\
\hline Escherichia coli & & & & \\
\hline Staphylococcus aureus & & & & \\
\hline
\end{tabular}

b)

\begin{tabular}{|c|c|c|c|c|}
\hline \multirow{2}{*}{ Microorganism } & \multicolumn{4}{|c|}{ Formulation content (\% odw) } \\
\hline & Reference & 0.15 & 0.2 & 0.3 \\
\hline Escherichia coli & & & & \\
\hline Staphylococcus aureus & & & & \\
\hline Aspergillus niger & & & & \\
\hline $\begin{array}{l}\text { Stichococcus bacillaris } \\
\text { Scenedesmus vaculatus }\end{array}$ & & & & \\
\hline
\end{tabular}

